\title{
Necroptosis Signaling Pathways in Stroke: From Mechanisms to Therapies
}

\author{
Huang Jun-Long ${ }^{\mathrm{a}, \#}$, Li Yi ${ }^{\mathrm{b}, \#}$, Zhao Bao-Lian ${ }^{\mathrm{c}}, \mathrm{Li} \mathrm{Jia-Si}^{\mathrm{d}}$, Zhang Ning ${ }^{\mathrm{a}}$, Ye Zhou-Heng ${ }^{\mathrm{a}}$, \\ Sun Xue-Jun ${ }^{\mathrm{a},{ }^{*}}$ and Liu Wen-Wu ${ }^{\mathrm{e}, *}$
} ${ }^{a}$ Department of Navy Aviation Medicine, Faculty of Naval Medicine, Second Military Medical University, Shanghai
200433, People's Republic of China; ${ }^{b}$ Department of Neurosurgery, Xinhua Hospital, Shanghai Jiaotong University,
Shanghai, 200092, People's Republic of China; ${ }^{c}$ Department of Naval Clinical Medicine, Second Military Medical Uni-
versity, Shanghai 200433, People's Republic of China; ${ }^{d}$ Department of Neurology, Changhai Hospital, Second Military
Medical University, Shanghai 200433, People's Republic of China; ${ }^{e}$ Department of Diving and Hyperbaric Medicine,
Faculty of Naval Medicine, Second Military Medical University, Shanghai 200433, People's Republic of China

\begin{abstract}
It has been confirmed that apoptosis, autophagy and necrosis are the three major modes of cell death. For a long time, necrosis is regarded as a deranged or accidental cell demise. In recent years, there is evidence showing that necrotic cell death can be a well regulated and orchestrated event, which is also known as programmed cell death or "necroptosis". Necroptosis can be triggered by a variety of external stimuli and regulated by a caspase-independent pathway. It plays a key role in the pathogenesis of some diseases including neurological diseases. In the past two decades, a variety of studies have revealed that the necroptosis related pathway is activated in stroke, and plays a crucial role in the pathogenesis of stroke. Moreover, necroptosis may serve as a potential target in the therapy of stroke because genetic or pharmacological inhibition of necroptosis has been shown to be neuroprotective in stroke in vitro and in vivo. In this review, we briefly summarize recent advances in necroptosis, introduce the mechanism and strategies targeting necroptosis in stroke, and finally propose some issues in the treatment of stroke by targeting necroptosis.
\end{abstract}

Keywords: Programmed cell death, necroptosis, stroke, RIP1, RIP3, MLKL, Nec-1.

\section{INTRODUCTION}

Stroke is caused by a poor blood flow to the brain, and can be divided into two main types: ischemic stroke and hemorrhagic stroke. Although the incidence of stroke is still increasing, the mortality of stroke tends to reduce in recent years due to the reinforcement of patients' education on stroke prevention [1], early diagnosis and therapy [2], establishment of stroke unit [3], timely thrombolysis [4], and improvement of quality of care [5]. However, stroke is still the second most common cause of death following ischemic heart disease, and accounts for $9 \%$ of all deaths world wide [6]. In addition, it has high disability and recurrence rate, increasing the economic burdens to the family and the society. Currently, the available therapeutic strategies for stroke include thrombolytic therapy, anticoagulants, anti-platelet drugs, and neuroprotective agents such as reactive oxygen species (ROS) scavenger [7], endothelial nitric oxide

\footnotetext{
*Address correspondence to these authors at the Department of Navy Aviation Medicine, Faculty of Naval Medicine, Second Military Medical University, No 800 Xiangyin Road, Yangpu District, Shanghai, 200433, P.R. China; Tel: +86-21-81871143; E-mail: sunxjk@hotmail.com and Department of Diving and Hyperbaric Medicine, Faculty of Naval Medicine, Second Military Medical University, No 800 Xiangyin Road, Yangpu District, Shanghai, 200433, P.R. China; Tel: +86-21-81871144;

E-mail: liuwenwu1980@hotmail.com

"Both Huang Jun-Long and Li Yi contribute to this paper equally.
}

synthase activator [8], mammalian target of rapamycin activator or inhibitor [9], and tumor necrosis factor receptorassociated factor 1 inhibitor [10]. However, thrombolytic therapy is limited due to the short time window and the efficacy of other therapies has not been confirmed in clinical trials so far. Thus, more effort is needed to develop new therapies for stroke on the basis of further understanding of the pathogenesis of stroke.

Stroke may trigger a variety of biochemical and molecular mechanisms leading to the neurological dysfunction including the activation of excitotoxic glutamatergic signaling [11], ionic imbalance [12], and excess production of ROS [7, 13]. The scathing mechanisms may proceed via nonprogrammed cell death (necrosis) or by programmed cell death (apoptosis or necroptosis) [14]. It has been confirmed that apoptosis, autophagy and necrosis are the three major modes of cell death [15]. Studies have revealed that cerebral ischemia may cause both necrosis and apoptosis of cells in the brain. At the infarct zone, neurons are mainly necrotic, while the main death form of neurons is apoptosis in the ischemic penumbra or the perifocal tissues during the first few hours after a stroke [16-18]. Autophagy takes an important role in adapting to the nutritional deprivation and eliminating aggregated proteins, but inappropriate activation of autophagy also in turn causes cell death in the ischemic brain injury. Thus, autophagy has been regarded as a double-edged sword with therapeutic potential in cerebral ischemia [19]. 
In the early 1970s, Kerr et al. put forward the term "apoptosis", a regulated cell death process, which is morphologically distinct from necrosis [20]. For a long period, necrosis is regarded as a deranged or accidental cell demise that is a passive process caused by overwhelming stress. Since the 1990s, the purely unregulated nature of necrosis was challenged that necrotic cell death, at least in part, can be a well regulated and orchestrated event as apoptosis [21, 22]. The accumulated knowledge has paved the way for the term of "programmed necrosis", which has not been introduced by Chan et al. until 2003 [23]. In 2005, Degterev et al. found that necrostatin-1 (Nec-1) could inhibit necrotic cell death mediated by downstream regulator receptor-interacting protein 1 (RIP1) of Fas/tumor necrosis factor receptor 1 (TNFR1), rather than apoptosis, in the condition of caspase- 8 inhibition in a model of ischemic brain injury. Furthermore, Nec-1 has a longer-time window in contrast of Z-VAD-fmk, an inhibitor of apoptosis [24]. These results show that this type of necrotic cell death can be controlled and occur later than apoptosis, and is termed "necroptosis" later [25]. With our understanding of the mechanism of necroptosis in ischemic neurons, it is possible to offer neuroprotection by interfering with necrosis. Caspase- 8 activity is partially dependent on the level of ATP, which is insufficient for the maintenance of caspase- 8 activity in the acute stage of cerebral ischemia because of a serious shortage of ATP production. Therefore, necroptosis is probably the major route of death of neurons in the acute stage of cerebral ischemia [26]. Moreover, therapy targeting necrosis has a longer-time window, which is clinically important. Thus, the elucidation of mechanisms underlying the necroptosis of neurons and other cells in the brain is helpful to develop new therapeutic targets and effective strategies for the treatment of stroke.

Recently, studies have implicated necroptosis in a variety of disease states, and it has a central pathophysiological relevance in some diseases including stroke [27], myocardial ischemia/reperfusion ( $\mathrm{I} / \mathrm{R}$ ) injury [28], atherosclerosis [29], renal $\mathrm{I} / \mathrm{R}$ injury [30], pancreatitis [31], inflammatory bowel disease [32] and other disorders. In this review, we briefly summarize recent advances in the necroptosis and introduce the mechanisms of necroptosis and clinical strategies targeting necroptosis in the therapy of stroke.

\section{CHARACTERISTICS OF NECROPTOSIS}

Necroptosis has some distinctive features compared to other modes of cell death, especially apoptosis (Table 1). Morphologically, necroptosis is characterized by morphology resembling unregulated necrosis: early loss of plasma membrane integrity, gain in cell volume and swelling organelles. In contrast, apoptosis is characterized by cell shrinkage, plasma membrane blebbing, and nuclear and organelle condensation and fragmentation. Biochemically, significant depletion of cellular ATP and leakage of intracellular contents are present during necroptosis, suggesting an energyconsuming process. Molecularly, necroptosis has no involvement of caspase and its signals are dependent on RIP1, receptor-interacting protein 3 (RIP3) and mixed lineage kinase domain-like protein (MLKL), while caspase activation is indispensible for the apoptosis. During the necroptosis, the permeabilization of plasma membrane, a major characteristic of necroptosis, may cause the release of damage associated molecular patterns (DAMPs) including mitochondrial DNA and high-mobility group box 1 protein, which may induce immune response and inflammation [33].

Although there are distinctive features between necroptosis and other cell death modes, there is still complicated interrelationship between necroptosis and other cell death pathways, and necroptosis has been viewed as a back-up process when apoptosis is abrogated [34] (Fig. 1).

\section{MECHANISMS AND REGULATION OF NECROPTOSIS (FIG. 2)}

\subsection{Initiation of Necroptosis}

Necroptosis can be induced by multiple triggers, including the tumor necrosis factor (TNF) family of cytokines, such as TNF, TNF-related apoptosis-inducing ligand and FasL [27, 35]; ROS [36, 37]; the activated Toll-like receptors (TLRs), such as TLR3 and TLR4 [38]; type I interferons (IFNs) [39] and certain pathogens [40-42].

The most extensively studied pathway leading to necroptosis is triggered by TNF- $\alpha /$ TNFR-induced pathway [43]. After the binding of TNF- $\alpha$ to TNFR1, the activated receptor may interact with RIP1 via the death domains (DD), which

Table 1. Comparisons between necroptosis and apoptosis.

\begin{tabular}{|c|c|}
\hline Necroptosis & Apoptosis \\
\hline \multicolumn{2}{|c|}{ Morphological markers } \\
\hline $\begin{array}{c}\text { Plasma membrane swelling and rupture; Cytoplasm swelling and } \\
\text { vacuolization; No nuclear fragmentation; Mitochondria and } \\
\text { organelle swelling }\end{array}$ & $\begin{array}{l}\text { Plasma membrane blebbing; Cytoplasm fragmentation; apoptotic body forma- } \\
\text { tion; Nuclear condensation and fragmentation; Organelle fragmentation }\end{array}$ \\
\hline \multicolumn{2}{|c|}{ Biochemical markers } \\
\hline ATP depletion; ROS production; Calcium and sodium influx & ATP increase; ROS production; Mitochondria outer membrane permeabilization \\
\hline \multicolumn{2}{|c|}{ Molecular markers } \\
\hline $\begin{array}{l}\text { Signaling by RIP1, RIP3, and MLKL; Regulation by death receptors; } \\
\text { Inhibition by caspases; Random DNA degradation; Extracellular re- } \\
\text { lease of DAMPs, such as mitochondrial DNA and HMGB1 }\end{array}$ & $\begin{array}{c}\text { Signaling by the Bcl-2 family proteins; Regulation by death receptors; Caspase } \\
\text { activation; DNA digestion by endonucleases; Cytosolic release of mitochondrial } \\
\text { cytochrome c, SMAC and AIF }\end{array}$ \\
\hline
\end{tabular}




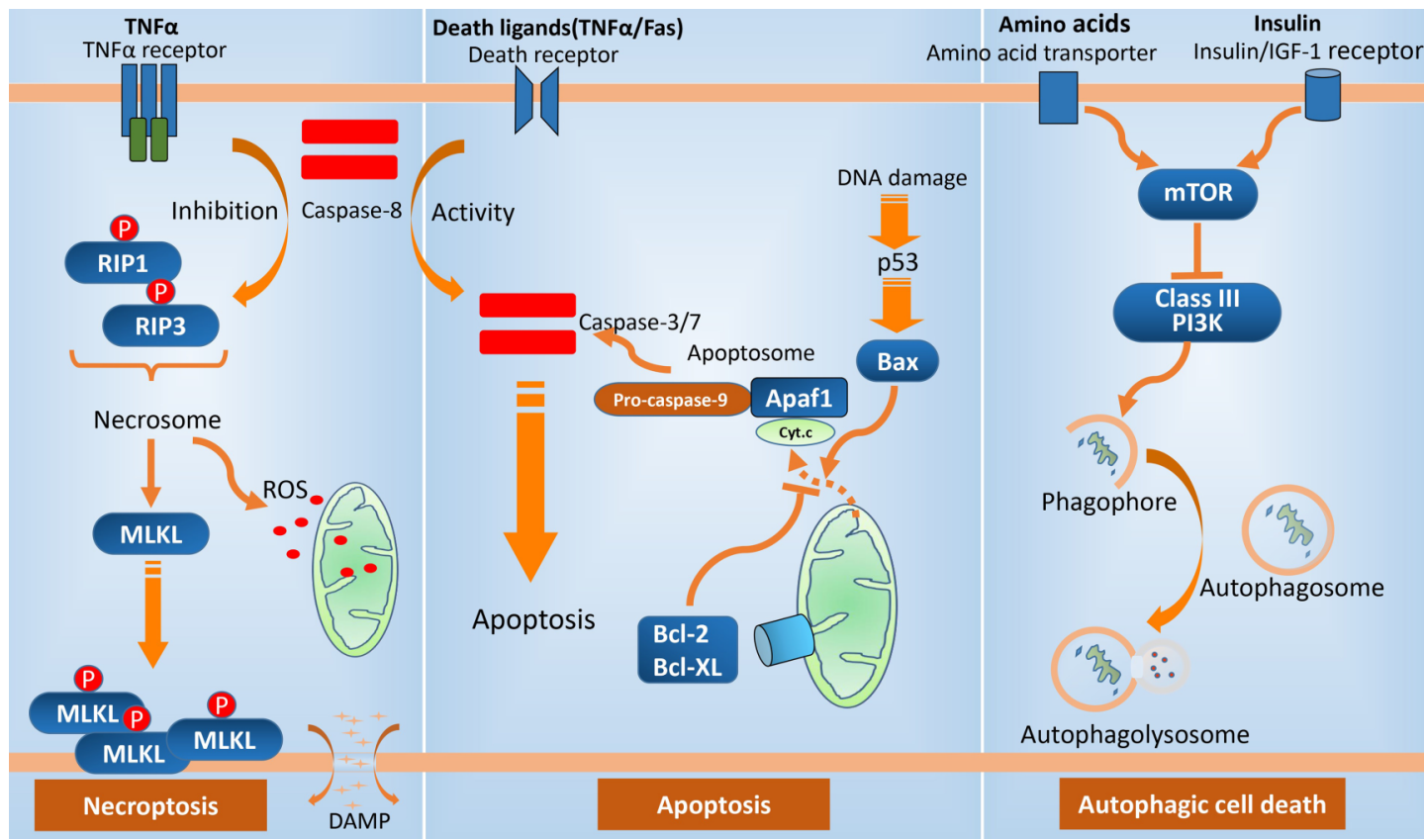

Fig. (1). Three modes of programmed cell death. Apoptosis, a programmed form of nonlytic cell death, can induce the activation of effector caspases via a variety of upstream signals. In the so-called "intrinsic cell death pathway," the P53 expression mediated by DNA damage triggers the production of Bax, a kind of pro-apoptotic protein, which can act to permeabilize the outer membranes of the mitochondria, releasing cytochrome $\mathrm{c}$, which results in the oligomerization of an adapter protein, APAF1. APAF1 then binds to and activates the initiator caspase, caspase-9, and apoptosome forms. Bcl-2 protein family has anti-apoptotic activity. In the extrinsic cell death pathway, normally, caspase 8 can trigger apoptosis by classical caspase cascade. In the presence of caspase 8 inhibition, necroptosis is activated by the phosphorylation of RIP1 and RIP3, and then necrosome forms, which may activate the executioner of necroptosis, MLKL, leading to necroptosis. Autophagy can be induced in response to environmental signals including amino acids, hormones, and energy consumption. The bestcharacterized regulatory protein, mTOR, can act to inhibit autophagy. The Class III PI3K complex contributes to membrane expansion, resulting in the formation of a closed double-membrane structure, the autophagosome, which fuses with a lysosome to form an autolysosome.

may recruit cellular inhibitor of apoptosis proteins (cIAPs) (such as cIAP1 and cIAP2) and subsequently form the plasma membrane associated complex, leading to the activation of nuclear factor $\kappa \mathrm{B}$ and mitogen-activated protein kinases (MAPKs). During this process, RIP1 can be polyubiquitinated by cIAPs and other E3 ubiquitin ligases [44]. The auto-ubiquitination and subsequent degradation of cIAPs induce the RIP1 deubiquitination, which is able to dissociate RIP1 from the cell membrane, causing its conversion from a pro-survival protein into a pro-death protein [45]. The binding of cytoplasmic RIP1 to FAS-associated death domain (FADD) may recruit procaspase-8, leading to the caspase- 8 activation. The activated caspase- 8 is able to inhibit the necroptosis through cleaving the key regulators of necroptosis (such as RIP1 and RIP3). When the caspase-8 activity is inhibited, cell apoptosis is inhibited and the necroptosis is induced [46]. The binding between RIP1 and RIP3 via their homotypic interaction motif (RHIM) domains may form a functional amyloid signaling complex, also known as "necrosome", which then induces the auto-phosphorylation of RIP3 and the subsequent execution of necrosis [47]. In addition to RIP1, it has been reported that there are other two RHIM-containing proteins, Toll/IL-1 receptor domaincontaining adaptor inducing IFN- $\beta$ (TRIF) and DNAdependent activator of interferon regulatory factors (DAI), can activate RIP3 within the necrosome [47]. For example, TLR3 as a biological stimulus exert necroptotic effects via the adapter protein TRIF [38]. Certain pathogens can also trigger necroptosis depending on the DNA-dependent activator of DAI $[42,48]$. Furthermore, IFNs trigger necroptosis independently of RIP1 via the IFN-induced protein kinase PKR [39]. Previous studies have shown that ROS may also regulate Smac mimetic/TNF- $\alpha$-induced necroptotic signaling [36]. Recently, Han et al. found that RIP1 autophosphorylation on serine residue 161 (S161) is promoted by mitochondrial ROS, which is indispensable for the recruitment of RIP3 into the necrosome. This suggests that the ROS can act as a new biological trigger, exerting necroptotic effects [37].

\subsection{Execution of Necroptosis}

Pseudokinase MLKL is a substrate of RIP3 and may serve as a major executioner of necroptosis $[49,50]$. There is evidence showing that RHIM dependent oligomerization and intramolecular autophosphorylation of RIP3 may recruit and phosphorylate MLKL, which induces a conformational change in the pseudokinase domain and the subsequent exposure of the 4-helical bundle domain [51, 52]. At present, two available non-exclusive models are proposed for the executioner mechanism of MLKL: (1) the plasma membrane serves as a platform for the recruitment of $\mathrm{Ca}^{2+}$ or $\mathrm{Na}^{+}$ion channel [53]; (2) the binding of MLKL to negatively charged phosphatidylinositol phosphates forms a direct pore-forming complex [54].

However, RIP3 also activates, independent of MLKL, ROS-driven necroptosis and FADD-mediated apoptosis [55, 


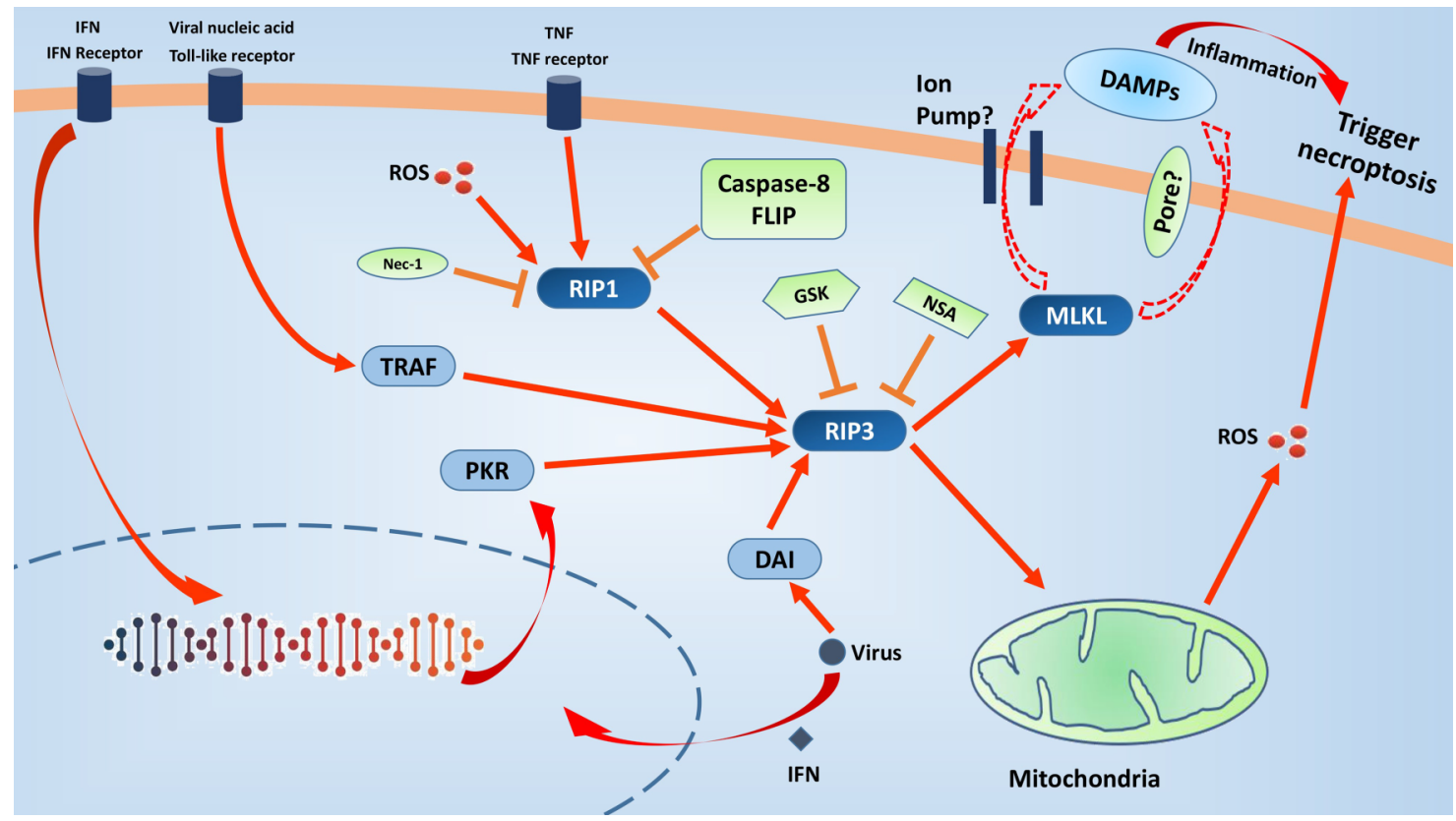

Fig. (2). Necroptosis-related signalling pathways and it's therapeutic targets. Necroptosis can be induced by multiple triggers,such as tumor necrosis factor (TNF), interferons (IFNs), viral nucleic acid, reactive oxygen species (ROS). Caspase-8 and cellular inhibitor of apoptosis proteins (cIAPs) prevent either RIP1 or RIP3 activation. When the caspase-8 activity is inhibited, necroptosis is induced. The binding between RIP1 and RIP3 via their homotypic interaction motif (RHIM) domains may form "necrosome", which then induces the autophosphorylation of RIP3 and subsequent execution of necrosis. There are other two RHIM-containing proteins, Toll/IL-1 receptor domaincontaining adaptor inducing IFN- $\beta$ (TRIF) and DNA-dependent activator of interferon regulatory factors (DAI), can activate RIP3 independently of RIP1 within the necrosome. Furthermore, IFNs also trigger necroptosis independently of RIP1 via the interferon-induced protein kinase PKR. ROS can activates RIP1 autophosphorylation on serine residue 161 (S161), and subsequently enables RIP1 to recruit RIP3. Pseudokinase MLKL is a substrate of RIP3 and may serve as a major executioner of necroptosis. At present, two available non-exclusive models are proposed for the executioner mechanism of MLKL. However, RIP3 also activates, independently of MLKL, ROS-driven necroptosis. Necroptosis may cause rapid plasma membrane permeabilization and the subsequent release of cell contents and exposure of damage associated molecular patterns (DAMPs), which in turn trigger necroptosis. In conclusion, necroptosis fuels the vicious circle via amplifying inflammatory response or mitochondrial ROS. Necrostatin-1 (Nec-1) was shown to inhibit the kinase activity of RIP1. Furthermore, there are three RIP3 kinase inhibitors, GSK'840, GSK'843 and GSK'872. Necrosulfonamide (NSA) inhibits MLKL and is able to protect human cells from necroptotic stimuli. These might be attractive therapeutic targets.

56]. RIP3 binds to $\mathrm{Ca}^{2+}$-calmodulin-dependent protein kinase (CaMKII) and, via phosphorylation, oxidation or both, activates CaMKII, which accounts for the opening of mitochondrial permeability transition pore and leads to myocyte necroptosis [57]. Thus, mitochondrial ROS not only trigger necroptosis but also act as an executive of necrosis, which means a positive feedback loop. It is worth mentioning that necroptosis may cause rapid plasma membrane permeabilization and the subsequent release of cell contents and exposure of DAMPs [58]; the pattern recognition receptor may recognize these DAMPs to activate immune response and induce the subsequent clearance of necrotic cells [59]. It has been found that defective clearance of necrotic cells may cause the persistence of inflammation and excessive tissue injury, which serves as a mechanism underlying the pathogenesis of some diseases [60]. In conclusion, necroptosis fuels the vicious circle via amplifying inflammatory response or mitochondrial ROS.

\subsection{Disposal of Necrotic Cells}

The macrophages may internalize necrotic cells by forming spacious macropinosomes [61], which is accompanied by macrophage ruffling and has involvement in the sorting of fluid-phase macromolecules [62]. Apoptotic cells may emit a series of well-defined 'find-me' $[63,64]$ and 'eat-me' signals. As in apoptosis, under some conditions, cells experiencing necrosis may also externalize phosphatidylserine before the plasma membrane permeabilization [65], which facilitates their recognition and internalization by phagocytes $[66,67]$.

\subsection{Inhibitors of Necropotisis}

The majority of the knowledge of necroptosis is gained using necroptosis inhibitors or genetic modification technique. To date, some inhibitors of necroptosis have been developed for the study of necroptosis.

\subsubsection{RIP1 Inhibitors}

The first inhibitor of necroptosis (Nec-1) was identified in 2005 in a phenotypic screen for small molecules that are able to inhibit the TNF induced necrosis in human monocytic U937 cells [24]. Nec-1 was subsequently shown to inhibit the kinase activity of RIP1 [EC ${ }_{50}=494 \mathrm{nM}$ )] [27]. However, Nec-1 is identical to the indoleamine-2,3- 
dioxygenase (IDO) enzyme inhibitor methyl-thiohydantointryptophan. In late studies, investigators developed a new inhibitor of necroptosis, Nec-1s (also called 7-Cl-O-Nec-1; $\left.\mathrm{EC}_{50}=206 \mathrm{nM}\right)$. Nec-1s lacks IDO inhibitory activity, but has increased plasma stability and increased specificity for RIP over a broad range of kinases as well as no toxic effect described for Nec-1 [68]. Several structurally distinct necrostatins (Nec-1, Nec-3, Nec-4, Nec-5 and Nec-7) are also developed, but Nec-7 $\left(\mathrm{EC}_{50}=10.6 \mu \mathrm{M}\right)$ does not inhibit RIP1 kinase [69].

\subsubsection{RIP3 Inhibitors}

There are three RIP3 kinase inhibitors, GSK'840, GSK' 843 and GSK' 872 . Of them, GSK' 843 and GSK' 872 at higher concentrations may promote TNF-induced RIP1 dependent apoptosis and caspase 8 activation [70], while GSK'840 exhibits the most specific profile. In addition, GSK'840 is particularly interesting because it does not induce RIP1 kinase activity-dependent apoptosis at higher concentrations, which is in contrast to GSK'843 and GSK'872. Currently, however, GSK'840 can not inhibit murine RIP3, which prevents its assessment in murine models.

\subsubsection{MLKL Inhibitors}

(E)-N-(4-(N-(4,6-dimethylpyrimidin-2-yl) sulfamoyl) phenyl)-3-(5- nitrothiophene - 2- yl) acrylamide (known as necrosulfonamide [NSA]) was the first compound reported to inhibit MLKL [49]. In fact, NSA was used to identify MLKL as a downstream target of RIP3. Of note, NSA is able to protect human cells from necroptotic stimuli, which is not found in murine cells because NSA alkylates the Cys86 of human MLKL and Cys86 is absent in murine MLKL. Thus, it is not suitable in murine preclinical models. In recent years, a new class of MLKL inhibitors based on 'compound 1' (also known as GW806742X or SYN-1215) is described to target the pseudokinase domain of MLKL [51].

\section{NECROPTOSIS ASSOCIATED PATHOLOGIES}

Over the past two decades, a variety of studies have shown that necroptosis is closely related to many pathologies, including I/R injury, inflammatory diseases, infection, autoimmune diseases and other disorders [71].

\subsection{I/R Injury}

Ischemia is caused by the obstruction of blood flow to a tissue, resulting in the insufficient supply of oxygen and nutrients, and if severe, in cell death. Reperfusion following the restoration of blood flow may cause a burst of ROS, also leading to cell death. The renal I/R was to be attenuated in RIP3-deficient mice [72], and RIP3 deficiency also decreased cardiac hypertrophy and inflammation after myocardial infarction [73]. In addition, RIP1 inhibitor Nec-1 is also able to attenuate myocardial I/R [74], which is ascribed to the inhibition of oxidative stress, necrosis and inflammation.

\subsection{Neurological Diseases}

Recent studies have shown that necroptosis is involved in the pathogenesis of some neurological diseases including stroke, traumatic brain injury (TBI), spinal cord injury (SCI) and neurodegenerative diseases. You et al. found administra- tion of Nec-1 before or 15 min after controlled cortical impact decreased brain tissue damage (days 14 and 35) and improved motor performance and spatial memory [75]. An IncRNA microarray analysis showed the expression of some lncRNAs related to necroptosis changed in rat hippocampus after TBI [76]. In a mouse TBI model, Nec-1 pretreatment was able to attenuate brain injury via inhibiting apoptosis and autophagy simultaneously [77]. In a SCI rat model, Wang et al. showed Nec-1 pre-treatment protected the spinal cord against injury via inhibiting both necroptosis and apoptosis [78]. In R6/2transgenic mouse model of Huntington's disease, Nec-1 was found to delay the disease onset, and the increased expression of RIP1 was observed at the onset of disease symptoms [79]. In primary newborn mouse cortical cells treated with aluminum, Nec-1 significantly improved the cell viability in a concentration dependent manner; Nec-1 also improves the learning and memory retention of mice treated with aluminum [80].

\subsection{Retinal Injury}

In retinitis pigmentosa mice with interphotoreceptor retinoid-binding protein (IRBP) deficiency $\left(\operatorname{Irbp}^{-/-}\right.$), the retina had increased expression of both RIP1 and RIP3, but inhibition of RIP1 kinase activity significantly prevented cone and rod photoreceptor degeneration [81]. In addition, RIP3deficiency resulted in the protection of cone cells against necroptosis in a mouse model of retinitis pigmentosa ( $\mathrm{rd} 10$ mice) [82]. In an experimental model of retinal detachment, more than 10-fold increase in RIP3 expression was observed after retinal detachment, and Nec-1 or RIP3 deficiency significantly alleviated necrotic changes and inhibited oxidative stress and mitochondrial release of AIF [83]. Nec-1 or RIP3 silencing also inhibited the retinal pigment epithelial cell death secondary to oxidative stress [84] and attenuated retinal I/R [85].

\subsection{Inflammation}

In TNF-induced systemic inflammatory response syndrome (SIRS), Duprez et al. found deletion of RIP3 or pretreatment with Nec-1 completely protected against lethal SIRS and reduced the amounts of circulating DAMPs [86]. RIP3-deficient mice could also be markedly protected from TNF- $\alpha$-mediated shock, while blocking necroptosis by Nec-1 did not protect from TNF- $\alpha / z V A D-m e d i a t e d ~ s h o c k$, and further accelerated time to death [87]. RIP3 expression was found to correlate with the sensitivity of pancreatic acinar cells to necroptosis, and in a cerulein-induced pancreatitis mouse model, RIP3 or MLKL deficiency protected mice from acute pancreatitis $[31,88]$, which suggests the involvement of necroptosis in the pathogenesis of pancreatitis. In ConA-induced acute hepatitis, increased RIP3 expression was observed in the liver, hepatocyte-specific caspase- 8 deletion increased necrotic damage and Nec-1 decreased hepatocyte necrotic cell death $[89,90]$. In acetaminophen-induced acute liver failure mice, hepatic RIP1 and RIP3 were activated, and either pretreatment or post-treatment with Nec-1 significantly attenuated APAP-induced acute liver failure and improved the survival by preventing APAP-induced necroptosis [91]. In mice after chronic ethanol feeding, increased RIP3 expression was detected in the liver [92], and a 
similar finding was also observed in patients with alcoholic liver disease [93], and RIP3-deficiency protected mice against both ethanol-induced liver injury and inflammation [93]. RIP3 expression also increased in the terminal ileum of patients with Crohn's disease, and the TNF induced cell death was associated with increased RIP3 expression, but prevented by Nec-1 in cultured intestinal organoids [94].

\subsection{Infection}

Vaccinia virus (VV) encodes the caspase inhibitor B13R/Spi2, which blocks apoptosis upon infection, but sensitizes cells to RIP1/RIP3-dependent necroptosis. VV infection induced the formation of pro-necrotic RIP1-RIP3 complex in the liver, accompanied by the induction of TNF expression and inflammation [95], but RIP3-deficient mice and RIP1 D138N/D138N mice showed attenuated necrotic tissue injury and inflammation $[95,96]$. Murine cytomegalovirus also encodes a necrotic inhibitor, vIRA, which can prevent premature host cell death upon infection. Studies have shown that vIRA may inhibit necrotic cell death after TNF treatment by disrupting the pronecrotic RIP1-RIP3 complex [97]. Necrotic cell death has also been observed after infection by other viruses, such as human immunodeficiency virus type-1, herpes simplex virus type- 1 and T3D, and Nec-1 pre-treatment is able to attenuate the cell death induced by these viruses [98-100].

\section{NECROPTOSIS AND STROKE}

Some studies have revealed that necroptosis is closely related to the pathogenesis of stroke as Nec-1 (Nec-1s) or genetic modulation of necroptosis related proteins may improve brain injury and neurological function after stroke (Table 2).

Liu et al. found necroptosis mediated TNF-induced toxicity of HT-22 hippocampal neuronal cells because these cells were sensitive to TNF- $\alpha$ only upon caspase blockage and subsequently underwent necrosis and the cell death was suppressed by knockdown of CYLD, RIP1, RIP3 or MLKL [101]. In cultured neurons exposed to hemoglobin or hemin (an in vitro model of intracerebral hemorrhage [ICH]), features of ferroptotic and necroptotic cell death, but not caspase-dependent apoptosis or autophagy, were observed, and chemical inhibitors of ferroptosis and necroptosis protected against hemoglobin- and hemin-induced toxicity (abrogating death by $>80 \%$ ) [102]. Qu et al. investigated the functions and mechanisms of MLKL in mediating neuronal damage in developing brain after hypoxia-ischemia (H/I). In neurons treated with oxygen-glucose deprivation (OGD) plus caspase inhibitor zVAD treatment (OGD/zVAD), RIP1 and RIP3 expressions were up-regulated and the interaction of RIP1-RIP3 with MLKL increased; siRNA mediated inhibition of MLKL attenuated neuronal death induced by OGD/zVAD [103]. In addition, induction of RIP1 protein instability was able to protect the primary neurons against $\mathrm{OGD} / \mathrm{zVAD}$ induced necroptosis [104]. In an in vitro model of global ischemia (hippocampal neurons exposed to OGD), RIP1 and RIP3 expression increased and both formed necrosomes, but caspase- 8 mRNA expression was transiently decreased following OGD; RIP3 knock-down (KD) abrogated OGDinduced necrotic neuronal death while RIP3 over-expression exacerbated neuronal death following OGD [105]. Necropto- sis was shown to be an early mechanism of cell death occurring within the first $24 \mathrm{~h}$ post-ischemic injury [106] and inversely linked to the caspase-dependent cell death [107].

Degterev et al. for the first time found that necroptosis contributes to mouse middle cerebral artery occlusion (MCAO) brain injury in vivo and the mechanism was distinct from that of apoptosis [24]. Moreover, they identified a specific and potent small-molecule inhibitor of necroptosis, Nec-1, which could block a critical step in the necroptosis (but not apoptosis) and exerted neurological protection in this animal model. Furthermore, the protective effect of 7 Cl-Nec-1 was also detectable even when it was administered $6 \mathrm{~h}$ after the onset of injury, and they speculated the extended time window of neuroprotection by $7-\mathrm{Cl}-\mathrm{Nec}-1$ in vivo might reflect a delayed induction of necroptosis during stroke. Xu et al. investigated the neuroprotection of Nec-1 in vivo and in vitro [108]. They found $\mathrm{Nec}-1$ could protect the mouse brain against I/R injury, and combined use of an apoptosis inhibitor Gly(14)-humanin and Nec-1 conferred synergistic neuroprotection in vivo and in vitro. In a global cerebral I/R injury model, neuronal death and rat mortality were greatly inhibited by Nec-1 and 3-MA (an autophagy inhibitor) pre-treatment, but not by Ac-DMQD-CHO (caspase-3 inhibitor) [109] and there was accompanied nuclear translocation and co-localization of RIP3 and AIF as well as their interaction after I/R injury. Moreover, they also evaluated the cell specificity of necroptosis. Results showed caspase- 8 was expressed richly in glial fibrillary acidic protein (GFAP) - positive astrocytes and Iba-1-positive microglia, but not in NeuN-positive neurons. Thus, they concluded that caspase- 3 and caspase- 8 are not involved in regulating hippocampal CA1 neuronal death induced by $I / R$ injury. In a global cerebral ischemia induced by the four-vessel occlusion method, Nec-1 induced inhibition of RIP3 up-regulation and nuclear translocation was also found to be related to its neuroprotection [110].

In a collagenase-induced ICH mouse model, Zhu et al. found the ultrastructural features of necrosis at $24 \mathrm{~h}$ after ICH by electron microscopy, and less necrotic cells were also found in RIP3-deficient mice after ICH [111]. In the same model, King et al. found Nec-1 was able to significantly reduce hematoma volume, limit cell death, reduce blood-brain barrier opening, attenuate edema development to sham level, and improve neurobehavioral outcome at $72 \mathrm{~h}$ after ICH [112]. Similar findings were found in the study of $\mathrm{Su}$ et al. [113]. In another in vivo ICH model established by the injection of autologous blood, inhibition of RIP1 by a specific chemical inhibitor or genetic knockdown attenuated brain edema and improved neurological score, which was also confirmed in an in vitro model using OxyHb-treated neurons [114]. Chang et al. also found the specific inhibitor Nec-1 also suppressed apoptosis and autophagy to exert neuroprotective effects after ICH [115]. In an endovascular perforation induced subarachnoid hemorrhage (SAH) rat model, SAH was found to up-regulate RIP1, RIP3, phosphorylated DRP1 and NLRP3 inflammasome, and Nec-1 treatment reduced RIP1, RIP3, phosphorylated DRP1 and NLRP3 inflammasome, subsequently alleviating brain injury secondary to SAH [116].

In neonatal brain $\mathrm{H} / \mathrm{I}$ model, blockade of RIP-1 kinase after $\mathrm{H} / \mathrm{I}$ afforded neuroprotection [106] and this protection 
Table 2. Animal studies on the treatment of stroke by targeting necroptosis.

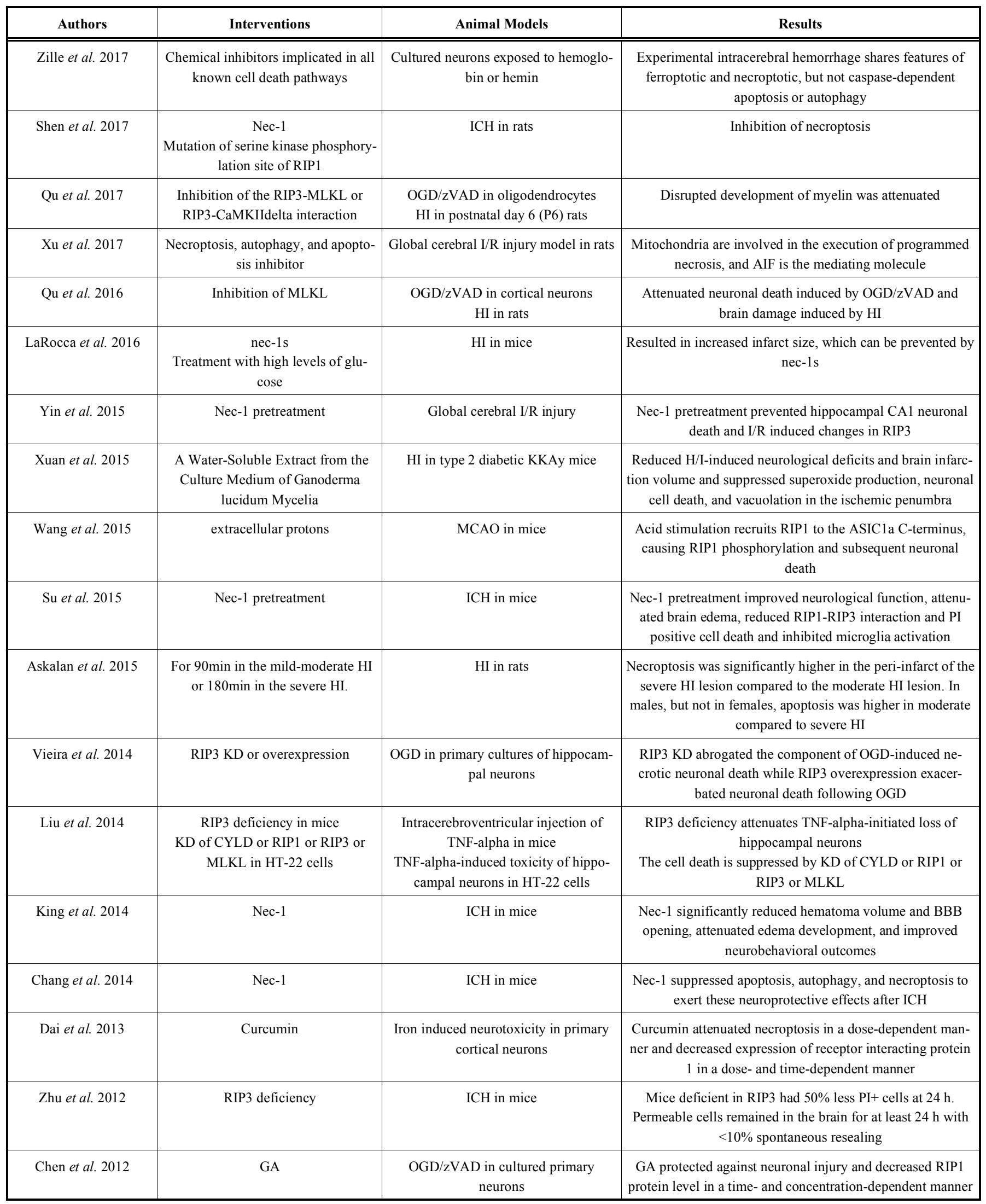




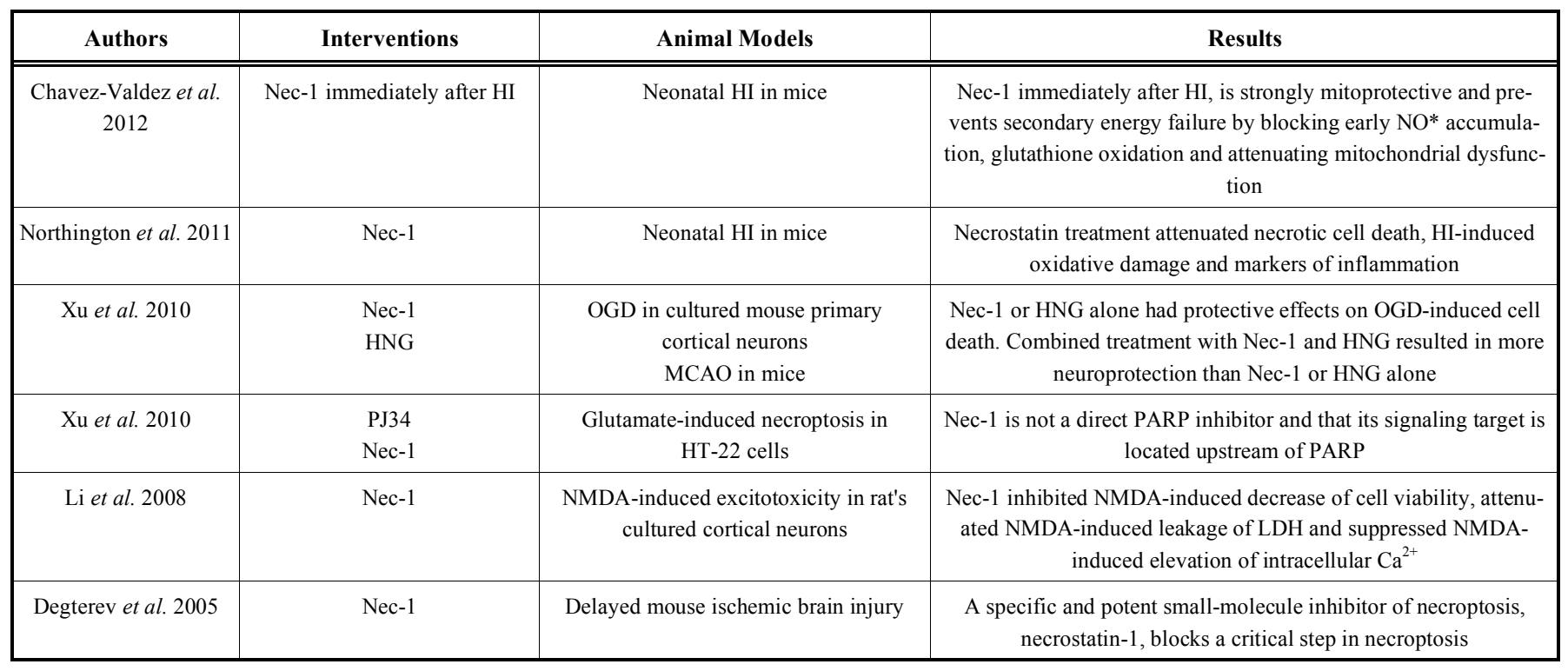

Abbreviations: RIP1: Receptor-interacting protein 1; RIP3: Receptor-interacting protein 3; MLKL: Mixed lineage kinase domain-like; Nec-1: Necrostatin-1, RIP1 inhibitor; Nec-1s: Nec-1 derivatives; KD: knock-down; I/R: Ischemia/reperfusion; HNG: Gly(14)-humanin, apoptosis inhibitor; GA: Geldanamycin; PJ34: a potent and specific inhibitor of poly(ADP-ribose)-polymerase (PARP); PI: Propidium iodide; BBB: Blood-brain barrier; ICH: Collagenase-induced intracerebral hemorrhage; OGD/zVAD: Oxygen-glucose deprivation plus caspase inhibitor zVAD treatment; OGD: Oxygen-glucose deprivation; HI: Hypoxia-ischemia; MCAO: Middle cerebral artery occlusion; ASIC1a: Acid-sensing ion channel 1; ICH: Intracerebral hemorrhage; LDH: Lactate dehydrogenase; NMDA: N-methyl-D-aspartic acid.

was possibly by interrupting RIP1-RIP3-driven oxidative injury and inflammation [117]. In the study of Qu et al., results showed siRNA mediated inhibition of MLKL was also able to reduce infarct area and improve neurological score in an experimental neonatal rat $\mathrm{H} / \mathrm{I}$ model [103]. In a mouse model of brain $\mathrm{H} / \mathrm{I}$ injury, the increased infarct size in mice with hyperglycemia was prevented by treatment with Nec$1 \mathrm{~s}$, suggesting that increased necroptosis accounts for the exacerbation of brain injury in conditions of hyperglycemia [118], and prevention of necroptosis was also found to attenuate $\mathrm{H} / \mathrm{I}$-induced injury of type 2 diabetic mouse brain [119]. In the moderately ischemic brain, necroptosis was predominantly found in the core of the lesion, the peri-infarct area of the severely ischemic brain had significantly more necroptosis than the peri-infarct area of the moderately injured brain, and necroptotic cell death was as active in the peri-infarct area as it was in the core of the lesion [120].

In oligodendrocytes treated by $\mathrm{OGD} / \mathrm{zVAD}$ in vitro, the expression of RIP3 was up-regulated, and the interaction of RIP3 with RIP1, MLKL, and CaMKIII increased; inhibition of the RIP3-MLKL or RIP3-CaMKII $\delta$ interaction attenuated $\mathrm{OGD} / \mathrm{zVAD}$ induced oligodendrocyte death, which was not found after inhibition of RIP3-RIP1 interaction. These protective mechanisms have involvement of the translocation of MLKL to the oligodendrocyte membrane and the phosphorylation of CaMKII $\delta$. In neonatal H/I rats, inhibition of RIP3MLKL or RIP3-CaMKII $\delta$ interaction attenuated the disrupted development of myelin [121]. Acidotoxicity is common among neurological disorders, such as ischemic stroke. Wang et al. investigated the relationship between acidosis and neuronal necroptosis [122]. They found acid stimulation could recruit RIP1 to the acid-sensing ion channel 1a (ASIC1a) Cterminus, causing RIP1 phosphorylation and subsequent neuronal death; in a mouse MCAO model, ASIC1a-RIP1 interaction and RIP1 phosphorylation were found in affected brain areas, and the Asicla deficiency significantly prevented RIP1 phosphorylation and brain damage, which indicates ASIC1a-mediated RIP1 activation is involved in ischemic neuronal injury. Overload of iron, which is released from hemoglobin, also contributes to brain injury after ICH. Dai et al. found iron overload promoted the necroptosis of primary cortical neurons but curcumin was able to attenuate ferrous chloride induced necroptosis [123]. Excitotoxicity is a key mechanism of tissue destruction in cerebral ischemia (stroke). Investigators found PARP activation was involved in the glutamate-induced necroptosis of HT-22 cells [124], and necroptosis was related to the N-Methyl-D-aspartateinduced excitotoxicity in rat cortical neurons [125].

\section{CONCLUSION AND PROSPECTIVE}

6.1. Although some studies have confirmed that necroptosis is involved in the pathogensis of stroke, and treatment targeting necroptosis related key proteins have been confirmed to be neuroprotective in different animal models and different cell types, few studies are undertaken to investigate the clinical use of necroptosis inhibitors or gene modification of necroptosis. As shown above, RIP1, RIP3 and MLKL are the three proteins specific to necroptosis. Thus, clinical strategies may target RIP1, RIP3, MLKL, or RIP1/RIP3 interaction, but inhibition of TNFR seems to be infeasible because TNFR related signaling pathways are related to some cell processes and not unique to necroptosis. Of note, NSA is able to inhibit MLKL in human cells, but may not affect the necroptosis in animal models. As shown in a lot of drugs, favorable results are usually obtained from pre-clinical studies, but less effectiveness is observed in clinical practice. Thus, more studies are needed to investigate the role of necroptosis in stroke in clinical settings.

6.2. As mentioned above, Nec-1 is identical to the IDO enzyme inhibitor methyl-thiohydantoin-tryptophan, and thus 
it might also inhibit the IDO enzyme, but Nec-1 has been used in a majority of studies, and more specific inhibitor 7Cl-Nec-1 is seldom used. Whether concomitant inhibition of IDO may bias the results is still unclear. Other inhibitors of necroptosis have never been used in stroke models.

6.3. Although a variety of studies investigated the therapeutic effects of necroptosis inhibitors in different disease models, few studies explored the potential toxicity of these inhibitors. Degterev et al. investigated the effects of Nec-1 on cell adhesion, actin and microtubule cytoskeletons, the morphology of various cellular compartments and others, and no detrimental effects were observed [24]. What are the half maximal inhibitory concentration and median lethal dose is needed to confirm in animal and cell models, and more studies are warranted to investigate the toxicity of these inhibitors of necroptosis, which is crucial for its clinical application. Moreover, the pharmacokinetics of these inhibitors (bioavailability, site where they are metabolized and the enzymes responsible for their metabolism, way in which they are excreted, their permeability to blood brain barrier and so on) are also needed to elucidate in animal models before its clinical use.

6.4. The dose-response curve is needed to be delineated to confirm the optimal dose of inhibitors. The optimal routes by which these drugs are used are also needed to investigate. Necroptosis inhibitors are usually administered intraperitoneally or intracerebroventricularly, and whether intravenous administration achieves similar effectiveness and which is the better route for administration are also needed to confirm.

6.5. As studied by Degterev et al., the new inhibitor 7-ClNec-1 was able to exert neuroprotective effects even administered at $6 \mathrm{~h}$ after stroke. Thus, what is the optimal time point at which these inhibitors still achieve neuroprotection is warranted to determine. This may be based on the dynamic change in cell necroptosis of the injured brain.

6.6. It has been confirmed that there is cross talk among different death modes. In the available studies, several also revealed that combined inhibition of necroptosis and apoptosis exerted synergistic neuroprotection in animal models. Whether this is clinically applicable is also required to confirm in more animal models.

6.7. As mentioned above, the role of necroptosis in the stroke has been investigated in oligodendrocytes, neurons and HT-22 cells. However, not only oligodendrocytes and neurons are involved in the pathogenesis of stroke, but also astrocytes, neural progenitor cell, vascular epithelial cells and other cell types in the brain are also closely related to the occurrence of stroke. Thus, what is the role of necroptosis of other cell types and whether there is an interaction between the necroptosis of two or more cell types are still needed to be studied in detail.

\section{LIST OF ABBREVIATIONS}

$\begin{array}{ll}\text { ASIC1a } & =\text { Acid-sensing ion channel } 1 \\ \text { cIAPs } & =\text { Cellular inhibitor of apoptosis proteins } \\ \text { CaMKII } & =\mathrm{Ca}^{2+} \text {-calmodulin-dependent protein kinase } \\ \text { DAMP } & =\text { Damage associated molecular pattern }\end{array}$

\begin{tabular}{|c|c|c|}
\hline DD & $=$ & Death domain \\
\hline DAI & $=$ & $\begin{array}{l}\text { DNA-dependent activator of interferon } \\
\text { regulatory factors }\end{array}$ \\
\hline FADD & $=$ & FAS-associated death domain \\
\hline GA & $=$ & Geldanamycin \\
\hline GFAP & $=$ & Glial fibrillary acidic protein \\
\hline $\mathrm{H} / \mathrm{I}$ & $=$ & Hypoxia-ischemia \\
\hline $\mathrm{ICH}$ & $=$ & Intracerebral hemorrhage \\
\hline IDO & $=$ & Indoleamine-2,3-dioxygenase \\
\hline $\mathrm{I} / \mathrm{R}$ & $=$ & Ischemia/reperfusion \\
\hline $\mathrm{KD}$ & $=$ & Knock-down \\
\hline $\mathrm{LDH}$ & $=$ & Lactate dehydrogenase \\
\hline LC3II & $=$ & microtubule-associated protein light chain-3 \\
\hline $\mathrm{MCAO}$ & $=$ & Middle cerebral artery occlusion \\
\hline MLKL & $=$ & Mixed lineage kinase domain-like \\
\hline Nec-1 & $=$ & Necrostatin-1, RIP1 inhibitor \\
\hline Nec-1s & $=$ & Nec-1 derivatives \\
\hline OGD & $=$ & Oxygen-glucose deprivation \\
\hline RIP1 & $=$ & Receptor-interacting protein 1 \\
\hline RIP3 & $=$ & Receptor-interacting protein 3 \\
\hline RHIM & $=$ & RIP homotypic interaction motif \\
\hline ROS & $=$ & Reactive oxygen species \\
\hline $\mathrm{SAH}$ & $=$ & Subarachnoid hemorrhage \\
\hline TLR & $=$ & Toll like receptor \\
\hline $\mathrm{TNF}$ & $=$ & Tumor necrosis factor \\
\hline TNFR & $=$ & Tumor necrosis factor receptor \\
\hline
\end{tabular}

\section{CONSENT FOR PUBLICATION}

Not applicable.

\section{CONFLICT OF INTEREST}

The authors declare no conflict of interest, financial or otherwise.

\section{ACKNOWLEDGEMENTS}

This study was supported by the National Natural Science Foundation of China (No. 81371316; 81772015). We thank Hu Qin in School of Medicine, Shanghai Jiaotong University for her constructive advice on this paper.

\section{REFERENCES}

[1] Daviet, J.C, Bonan, I.; Caire, J.M.; Colle, F.; Damamme, L.; Froger, J.; Leblond, C.; Leger, A.; Muller, F, Simon, O.; Thiebaut, M.; Yelnik, A. Therapeutic patient education for stroke survivors: Nonpharmacological management. A literature review. Ann. Phys. Rehabil. Med., 2012, 55(9-10), 641-56. [http://dx.doi.org/10.1016/j.rehab. 2012.08.011] [PMID: 23000090]

[2] Christerson, S. Also children and adolescents can suffer from stroke. Early diagnosis can improve prognosis. New guidelines for diagnosis and therapy. Lakartidningen, 2013, 110(41), 1799-802. [PMID: 24187893]

[3] Mehrpour, M.;Taghipour, S.; Abdollahi, S.; Oliaee, F.; Goran, A.; Motamed, M.; Ashayeri, R. Positive impact of stroke unit establish- 
ment on patient recovery in Firoozgar hospital. Med. J. Islam Repub. Iran, 2016, 30, 446. [PMID: 28210611]

[4] Emberson, J.; Lees, K.R.; Lyden, P.; Blackwell, L.; Albers, G.; Bluhmki, E.; Brott, T.; Cohen, G.; Davis S.; Donnan, G, Grotta, J, Howard, G.; Kaste, M.;Koga, M.; von Kummer, R.;Lansberg, M, Lindley, R.I.; Murray, G.; Olivot, J.M.; Parsons, M.; Tilley, B.; Toni, D.;Toyoda, K.; Wahlgren, N.; Wardlaw, J.; Whiteley, W.;del Zoppo, G.J.;Baigent, C.; Sandercock, P.; Hacke, W. Stroke Thrombolysis Trialists' Collaborative Group. Effect of treatment delay, age, and stroke severity on the effects of intravenous thrombolysis with alteplase for acute ischaemic stroke: a meta-analysis of individual patient data from randomised trials. Lancet, 2014, 384(9958), 1929-35. [http://dx.doi.org/10.1016/S0140-6736(14)

60584-5] [PMID: 25106063]

[5] O'Brien, E.C.; Wu, J.; Zhao, X, et al. Healthcare resource Availability, quality of care, and acute ischemic stroke outcomes. J. Am. Heart Assoc., 2017, 6. pii: e003813. [http://dx.doi.org/10.1161/JAHA.116. 003813] [PMID: 28159820]

[6] Kim, A.S.; Johnston, S.C. Temporal and geographic trends in the global stroke epidemic. Stroke, 2013, 44(6)(Suppl. 1), S123-5. [http://dx.doi. org/10.1161/STROKEAHA.111.000067] [PMID: 23709707]

[7] Davis, S.M.; Pennypacker, K.R. Targeting antioxidant enzyme expression as a therapeutic strategy for ischemic stroke. Neurochem. Int., 2016. [PMID: 28043837]

[8] Zhu, J.; Song, W.; Li, L.; Fan, X. Endothelial nitric oxide synthase: a potential therapeutic target for cerebrovascular diseases. Mol. Brain, 2016, 9, 30. [http://dx.doi.org/10.1186/s13041-016-0211-9] [PMID: 27000187]

[9] Maiese, K. Cutting through the complexities of mTOR for the treatment of stroke. Curr. Neurovasc. Res., 2014, 11(2), 177-86. [http:// dx.doi.org/10.2174/1567202611666140408104831] [PMID: 24712647]

[10] Lu,Y.Y.; Li, Z.Z.; Jiang, D.S.; Wang, L, Zhang, Y.; Chen, K, Zhang, X.F.; Liu, Y.; Fan, G.C.; Chen, Y.; Yang, Q.; Zhou, Y.; Zhang XD, Liu, D.P.; Li, H. TRAF1 is a critical regulator of cerebral ischaemiareperfusion injury and neuronal death. Nat. Commun., 2013, 4, 2852. [http://dx.doi.org/10.1038/ncomms3852] [PMID: 24284943]

[11] Martin, H.G.;Wang, Y.T. Blocking the deadly effects of the NMDA receptor in stroke. Cell, 2010, 140(2), 174-6. [http://dx.doi.org/ 10.1016/j.cell.2010.01.014] [PMID: 20141829]

[12] Besancon, E.; Guo, S.; Lok, J.; Tymianski, M.; Lo, E.H. Beyond NMDA and AMPA glutamate receptors: emerging mechanisms for ionic imbalance and cell death in stroke. Trends Pharmacol. Sci., 2008, 29(5), 268-75. [http://dx.doi.org/10.1016/j.tips.2008.02.003] [PMID: 18384889]

[13] Shirley, R.; Ord, E.N.; Work, L.M. Oxidative stress and the use of antioxidants in stroke. Antioxidants, 2014, 3(3), 472-501. [http://dx.doi.org/10.3390/antiox3030472] [PMID: 26785066]

[14] Puyal, J.; Ginet, V.; Clarke, P.G. Multiple interacting cell death mechanisms in the mediation of excitotoxicity and ischemic brain damage: a challenge for neuroprotection. Prog. Neurobiol., 2013, 105, 24-48. [http://dx.doi.org/10.1016/j.pneurobio.2013.03.002] [PMID: 23567504]

[15] Hotchkiss, R.S.; Strasser, A.; McDunn, J.E., Swanson, P.E. Cell death. N. Engl. J. Med., 2009, 361(16), 1570-83. [http://dx.doi.org/ 10.1056/NEJMra0901217] [PMID: 19828534]

[16] Linnik, M.D.; Zobrist, R.H.; Hatfield, M.D. Evidence supporting a role for programmed cell death in focal cerebral ischemia in rats. Stroke, 1993, 24(2002-2008), discussion 2008-2009. [http://dx.doi. org/10.1161/01.STR.24.12.2002]

[17] Charriaut-Marlangue, C.; Margaill, I.; Borrega, F.; Plotkine, M.; BenAri, Y. NG-nitro-L-arginine methyl ester reduces necrotic but not apoptotic cell death induced by reversible focal ischemia in rat. Eur. J. Pharmacol., 1996, 310(2-3), 137-40. [http://dx.doi.org/10.1016/ 0014-2999(96)00385-8] [PMID: 8884209]

[18] Guégan, C.; Ceballos-Picot, I.; Nicole, A.; Kato, H.; Onténiente, B.; Sola, B. Recruitment of several neuroprotective pathways after permanent focal ischemia in mice. Exp. Neurol., 1998, 154(2),371-80. [http://dx.doi.org/10.1006/exnr.1998.6913] [PMID: 9878175]

[19] Wei, K.; Wang, P.; Miao, C.Y. A double-edged sword with therapeutic potential: an updated role of autophagy in ischemic cerebral injury. CNS. Neurosci. Ther., 2012, 18(11), 879-86. [http://dx.doi.org/ 10.1111/cns.12005] [PMID: 22998350]

[20] Kerr, J.F.; Wyllie,. A.H.; Currie, A.R. Apoptosis: a basic biological phenomenon with wide-ranging implications in tissue kinetics. Br. $J$.
Cancer, 1972, 26(4), 239-57. [http://dx.doi.org/10.1038/bjc.1972.33] [PMID: 4561027]

[21] Vercammen, D.;Vandenabeele, P.; Beyaert, R.; Declercq, W.; Fiers, $\mathrm{W}$. Tumour necrosis factor-induced necrosis versus anti-Fas-induced apoptosis in L929 cells. Cytokine, 1997, 9(11), 801-8. [http://dx. doi.org/10.1006/cyto.1997.0252] [PMID: 9367540]

[22] Kawahara, A.; Ohsawa, Y.; Matsumura, H.; Uchiyama, Y.; Nagata, S. Caspase-independent cell killing by Fas-associated protein with death domain. J. Cell Biol., 1998, 143(5), 1353-60. [http://dx.doi. org/10.1083/jcb.143.5.1353] [PMID: 9832562]

[23] Chan, F.K.; Shisler, J.; Bixby, J.G.; Felices, M.; Zheng, L.; Appel, M.; Orenstein, J.; Moss, B.; Lenardo, M.J. A role for tumor necrosis factor receptor-2 and receptor-interacting protein in programmed necrosis and antiviral responses. J. Biol. Chem. 2003, 278(51), 5161321. [http://dx.doi.org/10.1074/jbc.M305633200] [PMID: 14532286]

[24] Degterev, A.; Huang, Z.; Boyce, M.; Li, Y.; Jagtap. P.; Mizushima, N.; Cuny, G.D.; Mitchison, T.J.; Moskowitz, M.A.; Yuan, J. Chemical inhibitor of nonapoptotic cell death with therapeutic potential for ischemic brain injury. Nat. Chem. Biol., 2005, l(2), 112-9. [http://dx. doi.org/10.1038/nchembio711] [PMID: 16408008]

[25] Linkermann, A.; Green, D.R. Necroptosis. N. Engl. J. Med., 2014 370(5), 455-65. [http://dx.doi.org/10.1056/NEJMra1310050] [PMID 24476434]

[26] Vanlangenakker, N.; Vanden, B.T, Krysko, D.V.; Festjens, N.; Vandenabeele, P. Molecular mechanisms and pathophysiology of necrotic cell death. Curr. Mol. Med., 2008, 8(3), 207-20. [http://dx. doi.org/10.2174/156652408784221306] [PMID: 18473820]

[27] Degterev, A.; Hitomi, J.; Germscheid, M.; Ch'en,, I..L.; Korkina, O.; Teng, X.; Abbott, D.; Cuny, G.D.; Yuan, C.; Wagner, G.; Hedrick, S.M.; Gerbe,r S. A.; Lugovskoy, A.; Yuan, J. Identification of RIP1 kinase as a specific cellular target of necrostatins. Nat. Chem. Biol., 2008, 4(5), 313-21. [http://dx.doi.org/10.1038/nchembio.83] [PMID: 18408713]

[28] Oerlemans, M.I.; Liu, J.; Arslan, F.; den Ouden, K.; van Middelaar, B.J.; Doevendans, P.A.; Sluijter, J.P. Inhibition of RIP1-dependent necrosis prevents adverse cardiac remodeling after myocardial ischemia-reperfusion in vivo. Basic Res. Cardiol., 2012, 107(4), 270. [http://dx.doi.org/10.1007/s00395-012-0270-8] [PMID: 22553001]

[29] Lin, J.; Li H.; Yang, M.; Ren, J.; Huang, Z.; Han, F.; Huang, J.; Ma, J.; Zhang, D.; Zhang, Z.; Wu, J.; Huang, D.; Qipao, M.; Jin, G.; Wu, Q, Huang Y.; Du, J.; Han, J. A role of RIP3-mediated macrophage necrosis in atherosclerosis development. Cell Reports, 2013, 3(1), 20010. [http://dx.doi.org/10.1016/j.celrep.2012.12.012] [PMID: 23333278]

[30] Linkermann, A.; Bräsen, J.H.; Himmerkus N.; Liu, S.; Huber, T.B.; Kunzendorf, U.; Krautwald, S. Rip1 (receptor-interacting protein kinase 1) mediates necroptosis and contributes to renal ischemia/ reperfusion injury. Kidney Int., 2012, 81(8), 751-61. [http://dx.doi. org/10.1038/ki.2011.450] [PMID: 22237751]

[31] He, S.; Wang, L.; Miao, L, Wang, T.; Du, F.; Zhao, L.; Wang, X. Receptor interacting protein kinase-3 determines cellular necrotic response to TNF-alpha. Cell, 2009, 137(6), 1100-11. [http://dx.doi.org/ 10.1016/j.cell.2009.05.021] [PMID: 19524512]

[32] Welz, P.S.; Wullaert, A.; Vlantis, K.; Kondylis, V.; FernándezMajada V.; Ermolaeva, M.; Kirsch, P.; Sterner-Kock, A.; van Loo G.; Pasparakis, M. FADD prevents RIP3-mediated epithelial cell necrosis and chronic intestinal inflammation. Nature, 2011, 477(7364), 330-4. [http://dx.doi.org/10.1038/nature10273] [PMID: 21804564]

[33] de Almagro, M.C.; Vucic, D. Necroptosis: Pathway diversity and characteristics. Semin. Cell Dev. Biol., 2015, 39,56-62. [http://dx. doi.org/10.1016/j.semcdb.2015.02.002] [PMID: 25683283]

[34] Vanden, B.T.; Kaiser, W.J.; Bertrand, M.J.; Vandenabeele, P. Molecular crosstalk between apoptosis, necroptosis, and survival signaling. Mol. Cell Oncol., 2015, 2(4), e975093. [http://dx.doi.org/ 10.4161/23723556.2014.975093] [PMID: 27308513]

[35] Holler, N.; Zaru, R.; Micheau, O.; Thome, M, Attinger A, Valitutti, S.; Bodmer, J.L.; Schneider, P.; Seed, B.; Tschopp J. Fas triggers an alternative, caspase-8-independent cell death pathway using the kinase RIP as effector molecule. Nat. Immunol., 2000, 1(6), 489-95. [http://dx.doi.org/10.1038/82732] [PMID: 11101870]

[36] Schenk, B.; Fulda, S. Reactive oxygen species regulate Smac mimetic/TNF $\alpha$-induced necroptotic signaling and cell death. Oncogene 2015, 34(47), 5796-806. [http://dx.doi.org/10.1038/onc.2015.35] [PMID 25867066]

[37] Zhang Y.; Su, S.S.; Zhao, S.; Yang, Z.; Zhong, C.Q.; Chen, X.; Cai, Q.; Yang, Z.H.; Huang, D.; Wu, R.; Han, J. RIP1 autophosphoryla- 
tion is promoted by mitochondrial ROS and is essential for RIP3 recruitment into necrosome. Nat. Commun., 2017, 8,14329. [http://dx. doi.org/10.1038/ncomms14329] [PMID: 28176780]

[38] Kaiser, W.J.; Sridharan, H. J.; Huang, CJ.; Mandal, PJ.; Upton, J.WJ.; Gough, P.J.; Sehon, C.A.; Marquis, R.WJ.; Bertin J, Mocarski, ES. Toll-like receptor 3-mediated necrosis via TRIF, RIP3, and MLKL. $J$. Biol. Chem., 2013, 288(43), 31268-79. [http://dx.doi.org/10.1074/ jbc.M113.462341] [PMID: 24019532]

[39] Thapa, R.J.; Nogusa, S.; Chen, P.; Maki, J.L.; Lerro, A.; Andrake, M.; Rall, G.F.; Degterev, A.; Balachandran, S. Interferon-induced RIP1/RIP3-mediated necrosis requires PKR and is licensed by FADD and caspases. Proc. Natl. Acad. Sci. USA., 2013,110(33), E3109-18. [http://dx.doi.org/10.1073/pnas.1301218110] [PMID: 23898178]

[40] Guo, H.; Kaiser, W.J.; Mocarski ES. Manipulation of apoptosis and necroptosis signaling by herpesviruses. Med. Microbiol. Immunol (Berl)., 2015, 204(3), 439-48. [http://dx.doi.org/10.1007/s00430-0150410-5] [PMID: 25828583]

[41] Upton, J.W.; Kaiser, W.J., Mocarski, E.S. Virus inhibition of RIP3dependent necrosis. Cell Host Microbe., 2010, 7(4), 302-13. [http://dx.doi.org/10.1016/j.chom.2010.03.006] [PMID: 20413098]

[42] Huang, Z.; Wu, S.Q.; Liang, Y.; Zhou, X, Chen W, Li L, Wu J, Zhuang, Q.; Chen, C.; Li J.; Zhong, C.Q.; Xia, W.; Zhou R, Zheng, C.;Han, J. RIP1/RIP3 binding to HSV-1 ICP6 initiates necroptosis to restrict virus propagation in mice. Cell Host Microbe., 2015, 17(2), 22942. [http://dx.doi.org/10.1016/j.chom.2015.01.002] [PMID: 25674982]

[43] Pasparakis, M.; Vandenabeele, P. Necroptosis and its role in inflammation. Nature, 2015,517(7534),311-20. [http://dx.doi.org/10.1038/ nature14191] [PMID: 25592536]

[44] Wertz, I.E.; Dixit, V.M. Ubiquitin-mediated regulation of TNFR1 signaling. Cytokine Growth Factor Rev., 2008, 19(3-4), 313-24. [http://dx.doi.org/10.1016/j.cytogfr.2008.04.014] [PMID: 18515172] Ofengeim, D.; Yuan, J. Regulation of RIP1 kinase signalling at the crossroads of inflammation and cell death. Nat. Rev. Mol. Cell Biol., 2013, 14(11), 727-36. [http://dx.doi.org/10.1038/nrm3683] [PMID: 24129419

[46] Wallach, D.; Kang T.B.; Yang, S.H.; Kovalenko, A. The in vivo significance of necroptosis: lessons from exploration of caspase-8 function. Cytokine Growth Factor Rev., 2014, 25(2), 157-65. [http://dx.doi.org/10.1016/j.cytogfr.2013.12.001] [PMID: 24411566]

[47] Vanden, B, T.; Hassannia, B.; Vandenabeele, P. An outline of necrosome triggers. Cell Mol. Life Sci., 2016, 73(11-12): 2137-52. [http://dx.doi.org/10.1007/s00018-016-2189-y] [PMID: 27052312]

[48] Wang, X.; Li, Y.; Liu, S.; Yu, X.; Li, L.; Shi, C.; He W.; Li, J, Xu L.; Hu, Z.; Yu, L.; Yang, Z.; Chen, Q.; Ge, L.; Zhang, Z.; Zhou, B.; Jiang, X.; Chen, S.; He, S. Direct activation of RIP3/MLKL-dependent necrosis by herpes simplex virus 1 (HSV-1) protein ICP6 triggers host antiviral defense. Proc. Natl. Acad. Sci. USA., 2014, 111(43), 1543843. [http://dx.doi.org/10.1073/pnas.1412767111] [PMID: 25316792]

[49] Sun, L.; Wang, H.; Wang, Z.; He, S.; Chen, S.; Liao, D.; Wang, L.; Yan, J.; Liu, W.; Lei, X.; Wang, X. Mixed lineage kinase domain-like protein mediates necrosis signaling downstream of RIP3 kinase. Cell, 2012, 148(1-2), 213-27. [http://dx.doi.org/10.1016/j.cell.2011.11.031] [PMID: 22265413]

[50] Zhao, J.; Jitkaew, S.; Cai, Z, Choksi, S.; Li, Q.; Luo, J.; Liu, Z.G. Mixed lineage kinase domain-like is a key receptor interacting protein 3 downstream component of TNF-induced necrosis. Proc. Natl. Acad. Sci. USA., 2012, 109(14), 5322-7. [http://dx.doi.org/10.1073/ pnas.1200012109] [PMID: 22421439]

[51] Hildebrand, J.M.; Tanzer, M.C.; Lucet, I.S.; Young, S.N.; Spall, S.K.; Sharma, P.; Pierotti, C.; Garnier, J.M.; Dobson, R.C.; Webb AI1, Tripaydonis, A.; Babon, J.J.; Mulcair, M. D.; Scanlon, M.J.; Alexander, W.S.; Wilks, A.F.; Czabotar, P. E.; Lessene, G.; Murphy, J.M.; Silke, J. Activation of the pseudokinase MLKL unleashes the four-helix bundle domain to induce membrane localization and necroptotic cell death. Proc. Natl. Acad. Sci. USA., 2014, 111(42), 15072-7. [http:// dx.doi.org/10.1073/pnas.1408987111] [PMID: 25288762]

[52] Murphy, J.M.; Czabotar, P.E.; Hildebrand, J.M.; Lucet, I.S.; Zhang, J.G.; Alvarez-Diaz, S.; Lewis, R.; Lalaoui, N.; Metcalf, D.;Webb, A.I.;Young, S.N.; Varghese, L.N.;Tannahill, G.M.; Hatchell, E.C, Majewski, I.J.;Okamoto, T.; Dobson, R. C.; Hilton, D.J.;Babon, J.J.; Nicola N.A, Strasser, A.; Silke, J.; Alexander, W.S. The pseudokinase MLKL mediates necroptosis via a molecular switch mechanism. Immunity, 2013, 39(3), 443-53. [http://dx.doi.org/10.1016/j. immuni.2013.06.018] [PMID: 24012422]
[53] Chen, X.; Li, W.; Ren, J.; Huang, D.; He, W.T.; Song, Y.; Yang, C.; Li W.; Zheng, X.; Chen, P.; Han, J. Translocation of mixed lineage kinase domain-like protein to plasma membrane leads to necrotic cell death. Cell Res., 2014, 24(1), 105-21. [http://dx.doi.org/10.1038/cr. 2013.171] [PMID: 24366341]

[54] Wang, H.; Sun, L.; Su, L.; Rizo, J.; Liu L.; Wang, L.F.; Wang, F.S.; Wang, X. Mixed lineage kinase domain-like protein MLKL causes necrotic membrane disruption upon phosphorylation by RIP3. Mol. Cell, 2014, 54(1), 133-46. [http://dx.doi.org/10.1016/j.molcel.2014. 03.003] [PMID: 24703947]

[55] Nogusa, S.; Thapa, R.J.; Dillon, C.P.; Liedmann, S.; Oguin, T.H. 3rd.; Ingram, J.P.; Rodriguez, D.A.; Kosoff, R.; Sharma, S.; Sturm, O.; Verbist, K, Gough, P.J.; Bertin, J, Hartmann, B.M.; Sealfon, S.C.; Kaiser, W.J.; Mocarski, E.S.;López, C.B.; Thomas, P.G.; Oberst, A.; Green, D.R.; Balachandran, S. RIPK3 activates parallel pathways of MLKL-Driven necrop-tosis and FADD-mediated Apoptosis to protect against influ-enza A virus. Cell Host Microbe, 2016, 20(1), 13-24. [http://dx.doi.org/10.1016/j.chom.2016.05.011] [PMID: 27321907]

[56] Zhang, D.W.; Shao, J.; Lin, J.; Zhang, N.; Lu, B.J.; Lin, S.C.; Dong, M.Q.; Han, J. RIP3, an energy metabolism regulator that switches TNF-induced cell death from apoptosis to necrosis. Science, 2009, 325(5938), 332-6. [http://dx.doi.org/10.1126/science.1172308] [PMID: 19498109]

[57] Zhang, T.; Zhang, Y.; Cui, M.; Jin, L.; Wang, Y.; Lv, F.; Liu, Y.;Zheng W.; Shang, H, Zhang, J.; Zhang, M.; Wu, H.; Guo, J.; Zhang, X.; Hu, X.; Cao, C.M.; Xiao, R.P. CaMKII is a RIP3 substrate mediating ischemia- and oxidative stress-induced myocardial necroptosis. Nat. Med., 2016, 22(2), 175-82. [http://dx.doi.org/10.1038/nm. 4017] [PMID: 26726877]

[58] Kaczmarek, A.; Vandenabeele, P.; Krysko, D.V. Necroptosis: the release of damage-associated molecular patterns and its physiological relevance. Immunity, 2013, 38(2), 209-23. [http://dx.doi.org/10.1016/ j.immuni.2013.02.003] [PMID: 23438821]

[59] Tsai, S.Y.; Segovia. J.A.; Chang, T.H.; Morris, I.R.; Berton, M.T.; Tessier, P.A.; Tardif, M.R.; Cesaro, A.; Bose, S. DAMP molecule S100A9 acts as a molecular pattern to enhance inflammation during influenza A virus infection: role of DDX21-TRIF-TLR4-MyD88 pathway. PLoS Pathog., 2014, 10(1), e1003848. [http://dx.doi.org/ 10.1371/journal.ppat.1003848] [PMID: 24391503]

[60] Vandenabeele, P.; Galluzzi, L.;Vanden, B. T.; Kroemer, G. Molecular mechanisms of necroptosis: an ordered cellular explosion. Nat. Rev. Mol. Cell Biol., 2010, 11(10), 700-14. [http://dx.doi.org/10. 1038/nrm2970] [PMID: 20823910]

[61] Krysko, D.V.; Brouckaert, G.; Kalai, M.; Vandenabeele, P.; D’Herde, K. Mechanisms of internalization of apoptotic and necrotic L929 cells by a macrophage cell line studied by electron microscopy. $J$. Morphol., 2003, 258(3), 336-45. [http://dx.doi.org/10.1002/jmor. 10161] [PMID: 14584035]

[62] Krysko, D.V.; Denecker, G.; Festjens, N.; Gabriels, S.; Parthoens, E.; D'Herde, K, Vandenabeele, P. Macrophages use different internalization mechanisms to clear apoptotic and necrotic cells. Cell Death Differ., 2006, 13(12), 2011-22. [http://dx.doi.org/10.1038/sj.cdd. 4401900] [PMID: 16628234]

[63] Lauber, K.; Bohn, E.; Kröber, S.M.; Xiao, Y.J.; Blumenthal, S.G.; Lindemann, R.K.; Marini, P.; Wiedig, C.; Zobywalski, A.; Baksh, S.; Xu Y.; Autenrieth, I.B.; Schulze-Osthoff, K.; Belka, C.; Stuhler G.; Wesselborg, S. Apoptotic cells induce migration of phagocytes via caspase-3-mediated release of a lipid attraction signal. Cell 2003, 113(6), 717-30. [http://dx.doi.org/10.1016/S0092-8674(03)00422-7] [PMID: 12809603]

[64] Elliott, M.R.; Chekenim F.B.;Trampontm P.C.; Lazarowskim, E. R.; Kadl, A.;Walk, S.F.; Park, D.;Woodson, R.I.; Ostankovich, M.; Sharmam, P.; Lysiak, J.J.; Harden, T.K.; Leitinger, N.; Ravichandran K. S. Nucleotides released by apoptotic cells act as a find-me signal to promote phagocytic clearance. Nature, 2009, 461(7261), 282-6. [http://dx.doi.org/10.1038/nature08296] [PMID: 19741708]

[65] Kryskom, O.; De Ridder, L.; Cornelissenm, M. Phosphatidylserine exposure during early primary necrosis (oncosis) in JB6 cells as evidenced by immunogold labeling technique. Apoptosis, 2004, 9(4), 495-500. [http://dx.doi.org/10.1023/B:APPT.0000031452.75162.75] [PMID: 15192332]

[66] Brouckaert, G.; Kalai. M.; Krysko, D.V, et al. Phagocytosis of necrotic cells by macrophages is phosphatidylserine dependent and does not induce inflammatory cytokine production. Mol. Biol. Cell., 2004, 
15(3), 1089-100. [http://dx.doi.org/10.1091/mbc.e03-09-0668] [PMID: 14668480]

[67] Hirt, U.A.; Leist, M. Rapid, noninflammatory and PS-dependent phagocytic clearance of necrotic cells. Cell Death Differ., 2003, 10(10),1156-64. [http://dx.doi.org/10.1038/sj.cdd.4401286] [PMID: 14502239]

[68] Takahashi, N.; Duprez, L.; Grootjans, S.; Cauwels, A.; Nerinckx, W, DuHadaway, J.B.; Goossens, V.; Roelandt, R.; Van Hauwermeiren, F.; Libert, C.; Declercq, W.; Callewaert, N, Prendergast, G.C.; Degterev, A.; Yuan, J.; Vandenabeele, P. Necrostatin-1 analogues: critical issues on the specificity, activity and in vivo use in experimental disease models. Cell Death Dis., 2012, 3, e437. [http:// dx.doi.org/10.1038/cddis.2012.176] [PMID: 23190609]

[69] Zheng, W.; Degterev, A.; Hsu, E.; Yuan, J.; Yuan, C. Structureactivity relationship study of a novel necroptosis inhibitor, necrostatin-7. Bioorg. Med. Chem. Lett., 2008, 18(18), 4932-5. [http://dx. doi.org/10.1016/j.bmcl.2008.08.058] [PMID: 18768316]

[70] Mandal, P.; Berger, S.B.; Pillay, S.; Moriwaki, K.;Huang, C, Guo H, Lich, J.D.; Finger, J.; Kasparcova, V.;Votta, B.;Ouellette M5, King B.W.; Winooski, D.; Lakdawala, A.S.; DeMartino, M.P.; Casillas, L.N.; Haile, P.A.; Sehon, C.A.; Marquis, R.W.; Upton, J, DaleyBauer, L.P.; Roback, L.; Ramia, N.; Dovey, C.M.; Carette J.E.; Chan, F.K.; Bertin, J.; Gough, P.J.; Mocarski, E.S.; Kaiser, W.J. RIP3 induces apoptosis independent of pronecrotic kinase activity. Mol. Cell 2014, 56(4), 481-95. [http://dx.doi.org/10.1016/j.molcel.2014.10.021] [PMID: 25459880]

[71] Jouan-Lanhouet, S.; Riquet, F.; Duprez, L.; Vanden, B. T.; Takahashi, N.; Vandenabeele, P. Necroptosis, in vivo detection in experimental disease models. Semin. Cell Dev. Biol., 2014,35: 2-13. [http://dx.doi.org/10.1016/j.semcdb.2014.08.010] [PMID: 25160988]

[72] Linkermann, A.; Bräsen, J.H.;Darding, M.; Jin, M.K.; Sanz, A.B.; Heller J.O.; De Zen, F.; Weinlich, R.; Ortiz, A.; Walczak H, Weinberg, J.M.; Green, D.R.; Kunzendorf, U.; Krautwald, S. Two independent pathways of regulated necrosis mediate ischemia-reperfusion injury. Proc. Natl. Acad. Sci. U.S.A., 2013, 110(29): 12024-9. [http:// dx.doi.org/10.1073/pnas. 1305538110] [PMID: 23818611]

[73] Luedde, M.; Lutz, M.; Carter, N.; Sosna J.; Jacoby, C.; Vucur, M.; Gautheron, J.; Roderburg, C.; Borg, N.; Reisinger, F.;Hippe, H.J.;Linkermann, A.; Wolf, M.J.; Rose-John, S.; Lüllmann-Rauch, R.; Adam, D.; Flögel, U.; Heikenwalder, M.; Luedde, T.; Fre,y N. RIP3, a kinase promoting necroptotic cell death, mediates adverse remodelling after myocardial infarction. Cardiovasc. Res., 2014, 103 (2), 206-16. [http://dx.doi.org/10.1093/cvr/cvu146] [PMID: 24920296]

[74] Lim, S.Y.; Davidson, S.M.; Mocanu M.M.; Yellon, D.M.; Smith, C.C. The cardioprotective effect of necrostatin requires the cyclophilin-D component of the mitochondrial permeability transition pore. Cardiovasc. Drugs Ther., 2007, 21(6), 467-9. [http://dx.doi.org/ 10.1007/s10557-007-6067-6] [PMID: 17965927]

[75] You, Z.; Savitz, S.I.; Yang, J.; Degterev, A.; Yuan, J.; Cuny, G.D.; Moskowitz, M.A.; Whalen, M.J. Necrostatin-1 reduces histopathology and improves functional outcome after controlled cortical impact in mice. J. Cereb. Blood Flow Metab., 2008, 28(9), 1564-73. [http://dx.doi.org/10.1038/jcbfm.2008.44] [PMID: 18493258]

[76] Wang, C.F., Zhao, C.C.; Weng, W. J.; Lei, J.; Lin, Y.; Mao, Q.; Gao, G.Y.; Feng, J.F.; Jiang, J.Y. Alteration in long non-coding RNA expression after traumatic brain injury in rats. J. Neurotrauma, 2017, 34(13), 2100-8. [http://dx.doi.org/10.1089/neu.2016.4642] [PMID: 28145813]

[77] Wang, Y. Q.; Wang, L.; Zhang, M.Y.; Wang, T.; Bao, H.J.; Liu, W. L.; Dai, D. K.; Zhang, L.; Chang, P.; Dong, W.W.; Chen, X.P.; Tao, L. Y. Necrostatin-1 suppresses autophagy and apoptosis in mice traumatic brain injury model. Neurochem. Res., 2012, 37(9), 1849-58. [http://dx.doi.org/10.1007/s11064-012-0791-4] [PMID: 22736198]

[78] Wang, Y.; Wang, H.; Tao, Y.; Zhang, S.; Wang, J.; Feng, X. Necroptosis inhibitor necrostatin-1 promotes cell protection and physiological function in traumatic spinal cord injury. Neuroscience, 2014, 266, 91-101. [http://dx.doi.org/10.1016/j.neuroscience.2014.02.007] [PMID: 24561219]

[79] Zhu, S.; Zhang, Y.;Bai, G.; Li, H. Necrostatin-1 ameliorates symptoms in R6/2 transgenic mouse model of Huntington's disease. Cell Death Dis., 2011, 2, e115. [http://dx.doi.org/10.1038/cddis.2010.94] [PMID: 21359116]

[80] Qinli, Z.; Meiqing, L.; Xia, J.; Li, X.; Weili, G.; Xiuliang, J.; Junwei, J.; Hailan, Y.; Ce, Z.; Qiao, N. Necrostatin-1 inhibits the degeneration of neural cells induced by aluminum exposure. Restor. Neurol. Neurosci., 2013, 31(5), 543-55. [PMID: 23735313]
[81] Sato, K.; Li, S.; Gordon, W.C.; He, J.; Liou, G.I.; Hill, J.M.; Travis, G.H.; Bazan, N.G.; Jin, M. Receptor interacting protein kinasemediated necrosis contributes to cone and rod photoreceptor degeneration in the retina lacking interphotoreceptor retinoid-binding protein. J. Neurosci., 2013, 33(44), 17458-68. [http://dx.doi.org/10.1523/ JNEUROSCI.1380-13.2013] [PMID: 24174679]

[82] Murakami, Y.; Matsumoto, H.; Roh, M.; Suzuki, J.; Hisatomi, T.; Ikeda Y.; Miller, J.W.; Vavvas, D.G. Receptor interacting protein kinase mediates necrotic cone but not rod cell death in a mouse model of inherited degeneration. Proc. Natl. Acad. Sci. USA., 2012, 109(36), 14598-603. [http://dx.doi.org/10.1073/pnas.1206937109] [PMID: 22908283]

[83] Trichonas, G.; Murakami, Y.; Thanos, A.; Morizane, Y.;Kayama, M.; Debouck, C.M.; Hisatomi, T.; Miller, J.W.; Vavvas, D.G. Receptor interacting protein kinases mediate retinal detachment-induced photoreceptor necrosis and compensate for inhibition of apoptosis. Proc. Natl. Acad. Sci. USA., 2010, 107(50), 21695-700. [http://dx.doi.org/ 10.1073/pnas.1009179107] [PMID: 21098270]

[84] Hanus, J.; Zhang, H.; Wang, Z.; Liu, Q.; Zhou, Q.; Wang, S. Induction of necrotic cell death by oxidative stress in retinal pigment epithelial cells. Cell Death Dis., 2013, 4, e965. [http://dx.doi.org/ 10.1038/cddis.2013.478] [PMID: 24336085]

[85] Rosenbaum, D.M.; Degterev, A.; David, J.; Rosenbaum PS, Roth S.; Grotta, J.C.; Cuny G.D.; Yuan, J.; Savitz, S.I. Necroptosis, a novel form of caspase-independent cell death, contributes to neuronal damage in a retinal ischemia-reperfusion injury model. J. Neurosci. Res., 2010, 88(7),1569-76. [PMID: 20025059]

[86] Duprez, L.; Takahashi, N.; Van Hauwermeiren, F.; et al. RIP kinasedependent necrosis drives lethal systemic inflammatory response syndrome. Immunity, 2011, 35(6), 908-18. [http://dx.doi.org/10. 1016/j.immuni.2011.09.020] [PMID: 22195746]

[87] Linkermann, A.; Bräsen, J.H.; De Zen, F.; Weinlich, R. Schwendener, R.A.; Green, D.R.; Kunzendorf, U.; Krautwald, S. Dichotomy between RIP1- and RIP3-mediated necroptosis in tumor necrosis factor- $\alpha$-induced shock. Mol. Med., 2012, 18,577-86. [http:// dx.doi.org/10.2119/molmed.2011.00423] [PMID: 22371307]

[88] Wu, J.; Huang, Z.; Ren, J.; Zhang, Z.; He, P.; Li, Y.; Ma, J.; Chen, W.; Zhang, Y.; Zhou, X.; Yang, Z.; Wu, S.Q.; Chen, L.; Han, J. Mlk knockout mice demonstrate the indispensable role of Mlkl in necroptosis. Cell Res., 2013, 23(8), 994-1006. [http://dx.doi.org/10.1038/ cr.2013.91] [PMID: 23835476]

[89] Jouan-Lanhouet, S.; Arshad, M.I.; Piquet-Pellorce, C, Martin-Chouly, C.; Le Moigne-Muller, G.; Van Herreweghe, F.; Takahashi, N.; Sergent O, Lagadic-Gossmann, D.; Vandenabeele, P, Samson, M.; Dimanche-Boitrel, M.T. TRAIL induces necroptosis involving RIPK1/RIPK3-dependent PARP-1 activation. Cell Death Differ., 2012, 19(12), 2003-14. [http://dx.doi.org/10.1038/cdd.2012.90] [PMID: 22814620]

[90] Liedtke, C.; Bangen, J.M.; Freimuth, J.; Beraza, N.; Lambertz D, Cubero, F.J.; Hatting, M.; Karlmark, K.R, Streetz, K.L.; Krombach G.A.; Tacke, F.; Gassler, N.; Riethmacher, D.; Trautwein, C. Loss of caspase-8 protects mice against inflammation-related hepatocarcinogenesis but induces non-apoptotic liver injury. Gastroenterology, 2011, 141(6), 2176-87. [http://dx.doi.org/10.1053/j.gastro.2011.08. 037] [PMID: 21878202]

[91] Zhang, Y.F.; He, W.; Zhang, C.; Liu, X.J.; Lu, Y.; Wang, H.; Zhang, Z.H.; Chen, X.; Xu, D.X. Role of receptor interacting protein (RIP)1 on apoptosis-inducing factor-mediated necroptosis during acetaminophen-evoked acute liver failure in mice. Toxicol. Lett., 2014, 225(3), 44553. [http://dx.doi.org/10.1016/j.toxlet.2014.01.005] [PMID: 24440347]

[92] Roychowdhury, S.; Chiang, D.J.; Mandal, P.; McMullen, M.R.; Liu, X.; Cohen, J.I.; Pollard, J.; Feldstein, A.E.; Nagy, L.E. Inhibition of apoptosis protects mice from ethanol-mediated acceleration of early markers of $\mathrm{CCl} 4$-induced fibrosis but not steatosis or inflammation. Alcohol Clin. Exp. Res., 2012, 36(7), 1139-47. [http://dx.doi.org/ 10.1111/j.1530-0277.2011.01720.x] [PMID: 22273278]

[93] Roychowdhury, S.; McMullen, M.R.; Pisano, S.G.; Liu, X.; Nagy, L.E. Absence of receptor interacting protein kinase 3 prevents ethanol-induced liver injury. Hepatology, 2013, 57(5), 1773-83. [http:// dx.doi.org/10.1002/hep.26200] [PMID: 23319235]

[94] Günther, C.; Martini, E.; Wittkopf, N.; Amann, K.; Weigmann, B.; Neumann, H.; Waldner, M. J.; Hedrick, S.M.; Tenzer, S.; Neurath M.F.; Becker, C. Caspase- 8 regulates TNF- $\alpha$-induced epithelial necroptosis and terminal ileitis. Nature, 2011, 477(7364), 335-9. [http://dx.doi.org/10.1038/nature10400] [PMID: 21921917] 
[95] Cho, Y.S.; Challa, S.; Moquin, D.; Genga, R.; Ray, T.D.; Guildford, M.; Chan, F.K. Phosphorylation-driven assembly of the RIP1-RIP3 complex regulates programmed necrosis and virus-induced inflammation. Cell, 2009; 137(6), 1112-23. [http://dx.doi.org/10.1016/ j.cell.2009.05.037] [PMID: 19524513]

[96] Polykratis, A.; Hermance, N.; Zelic, M.; Roderick, J.; Kim, C.; Van, T.M.; Lee, T.H.; Chan, F.K.M.; Pasparakis, M.; Kelliher, M. A. Cutting edge: RIPK1 Kinase inactive mice are viable and protected from TNF-induced necroptosis in vivo. J. Immunol., 2014, 193(4), 1539-43. [http://dx.doi.org/10.4049/jimmunol.1400590] [PMID: 25015821]

[97] Mack, C.; Sickmann, A.; Lembo, D.; Brune, W. Inhibition of proinflammatory and innate immune signaling pathways by a cytomegalovirus RIP1-interacting protein. Proc. Natl. Acad. Sci. U.S.A., 2008, 105(8),3094-9. [http://dx.doi.org/10.1073/pnas.0800168105] [PMID: $18287053]$

[98] Peri, P.; Nuutila, K.; Vuorinen, T.; Saukko, P.; Hukkanen, V. Cathepsins are involved in virus-induced cell death in ICP4 and Us3 deletion mutant herpes simplex virus type 1 -infected monocytic cells. J. Gen. Virol., 2011, 92(Pt 1),173-80. [http://dx.doi.org/10.1099/vir.0. 025080-0] [PMID: 20881085]

[99] Berger, A.K.; Danthi, P. Reovirus activates a caspase-independent cell death pathway. MBiol., 2013, 4(3), e00178-13. [http://dx. doi.org/10.1128/mBio.00178-13] [PMID: 23674612]

[100] Pan, T.; Wu, S.; He, X.; Luo, H.; Zhang, Y.; Fan, M.; Geng, G.; Ruiz, V,C.; Zhang, J.; Mills, L.; Bai, C.; Zhang, H. Necroptosis takes place in human immunodeficiency virus type-1 (HIV-1)-infected CD4+ T lymphocytes. PLoS One, 2014, 9(4), e93944. [http://dx.doi.org/ 10.1371/journal.pone.0093944] [PMID: 24714696]

[101] Liu, S.; Wang, X.; Li, Y.; Xu, L.; Yu, X.; Ge, L.; Li, J.; Zhu, Y.; He, S. Necroptosis mediates TNF-induced toxicity of hippocampal neurons. BioMed. Res. Int., 2014, 2014, 290182. [PMID: 25093162]

[102] Zille, M.; Karuppagounder, S.S.; Chen, Y.; Gough, P.J.; Ber-tin, J.; Finger, J.; Milner, TA.; Jonas, EA.; Ratan, R.R. Neu-ronal death after hemorrhagic stroke In Vitro and In Vivo shares features of ferroptosis and necroptosis. Stroke, 2017, 48(4), 1033-43. [http:// dx.doi.org/10.1161/STROKEAHA.116.015609] [PMID: 28250197]

[103] Qu, Y.; Shi, J.; Tang, Y.; Zhao, F.; Li, S.; Meng, J.; Tang, J.; Lin, X.; Peng, X.; Mu, D. MLKL inhibition attenuates hypoxia-ischemia induced neuronal damage in developing brain. Exp. Neurol., 2016, 279, 223-31. [http://dx.doi.org/10.1016/j.expneurol.2016.03.011] [PMID: 26980487]

[104] Chen, W.W.; Yu, H.; Fan, H.B.; Zhang, C.C.; Zhang, M.; Zhang, C.; Cheng, Y.; Kong, J, Liu, C.F.; Geng, D.; Xu, X. RIP1 mediates the protection of geldanamycin on neuronal injury induced by oxygenglucose deprivation combined with zVAD in primary cortical neurons. J. Neurochem., 2012, 120(1), 70-7. [http://dx.doi.org/10.1111/ j.1471-4159.2011.07526.x] [PMID: 21985437]

[105] Vieira, M.; Fernandes, J.; Carreto, L.; Anuncibay-Soto, B.; Santos, M.; Han, J.; Fernández-López, A.; Duarte, C.B.; Carvalho, A.L.; Santos, A.E. Ischemic insults induce necroptotic cell death in hippocampal neurons through the up-regulation of endogenous RIP3. Neurobiol. Dis., 2014, 68, 26-36. [http://dx.doi.org/10.1016/j.nbd.2014. 04.002] [PMID: 24746856]

[106] Chavez-Valdez, R.; Martin, L.J.; Flock, D. L.; Northington, F.J. Necrostatin-1 attenuates mitochondrial dysfunction in neurons and astrocytes following neonatal hypoxia-ischemia. Neuroscience, 2012, 219, 192-203. [http://dx.doi.org/10.1016/j.neuroscience.2012.05.002] [PMID: 22579794]

[107] Northington, F.J.; Chavez-Valdez, R.; Martin, L.J. Neuronal cell death in neonatal hypoxia-ischemia. Ann. Neurol., 2011, 69(5), 74358. [http://dx.doi.org/10.1002/ana.22419] [PMID: 21520238]

[108] Xu, X.; Chua, K.W.; Chua, C.C.; Liu, C. F.; Hamdy, R.C.; Chua, B.H. Synergistic protective effects of humanin and necrostatin-1 on hypoxia and ischemia/reperfusion injury. Brain Res., 2010, 1355, 18994. [http://dx.doi.org/10.1016/j.brainres.2010.07.080] [PMID: 20682300]

[109] Xu, Y.; Wang, J.; Song, X.; Qu, L.; Wei, R.; He, F.; Wang, K.; Luo, B. RIP3 induces ischemic neuronal DNA degradation and programmed necrosis in rat via AIF. Sci. Rep., 2016, 6, 29362. [http://dx.doi.org/10.1038/srep29362] [PMID: 27377128]

[110] Yin, B.; Xu, Y.; Wei, R.L.; He, F.; Luo, B.Y.; Wang, J.Y. Inhibition of receptor-interacting protein 3 upregulation and nuclear translocation involved in Necrostatin-1 protection against hippocampal neuronal programmed necrosis induced by ischemia/reperfusion injury.
Brain Res., 2015, 1609, 63-71. [http://dx.doi.org/10.1016/j.brainres. 2015.03.024] [PMID: 25801119]

[111] Zhu, X.; Tao, L.; Tejima-Mandeville, E.; Qiu, J.; Park, J.; Garber, K, Ericsson, M.; Lo, E.H.; Whalen, M.J. Plasmalemma permeability and necrotic cell death phenotypes after intracerebral hemorrhage in mice. Stroke, 2012, 43(2), 524-31. [http://dx.doi.org/10.1161/ STROKEAHA.111.635672] [PMID: 22076006]

[112] King, M.D.; Whitaker-Lea, W.A.; Campbell, J.M.; Alleyne, C.H. Jr.; Dhandapani, K.M. Necrostatin-1 reduces neurovascular injury after intracerebral hemorrhage. Int. J. Cell Biol., 2014, 2014, 495817. [http://dx.doi.org/10.1155/2014/495817] [PMID: 24729786]

[113] Su, X.; Wang, H.; Kang, D.; Zhu, J.; Sunm Q.; Li, T.; Dingm K. Necrostatin-1 ameliorates intracerebral hemorrhage-induced brain injury in mice through inhibiting RIP1/RIP3 pathway. Neurochem. Res., 2015, 40(4), 643-50. [http://dx.doi.org/10.1007/s11064-0141510-0] [PMID: 25576092]

[114] Shen, H.; Liu, C.; Zhang, D.; Yao, X.; Zhang, K.; Li ,H.; Chen, G. Role for RIP1 in mediating necroptosis in experimental intracerebral hemorrhage model both in vivo and in vitro. Cell Death Dis., 2017, 8(3), e2641. [http://dx.doi.org/10.1038/cddis.2017.58] [PMID: 28252651]

[115] Chang, P.; Dong, W.; Zhang, M.; Wang, Z.; Wang, Y.; Wang, T.; Gao, Y.; Meng, H.; Luo, B.; Luo, C.; Chen, X.; Tao, L . Antinecroptosis chemical necrostatin-1 can also suppress apoptotic and autophagic pathway to exert neuroprotective effect in mice intracerebral hemorrhage model. J. Mol. Neurosci., 2014, 52(2), 242-9. [http://dx.doi.org/10.1007/s12031-013-0132-3] [PMID: 24122153]

[116] Zhou, K.; Shi, L.; Wang, Z.; Zhou, J.; Manaenko, A, Reis, C.; Chen, S.; Zhang, J. RIP1-RIP3-DRP1 pathway regulates NLRP3 inflammasome activation following subarachnoid hemorrhage. Exp. Neurol., 2017, 295, 116-24. [http://dx.doi.org/10.1016/j.expneurol.2017.06. 003] [PMID: 28579326]

[117] Northington, F.J.; Chavez-Valdez, R.; Graham, E.M.; Razdan, S.; Gaudam E.B.; Martin, L.J. Necrostatin decreases oxidative damage, inflammation, and injury after neonatal HI. J. Cereb. Blood Flow Metab., 2011, 31(1), 178-89. [http://dx.doi.org/10.1038/jcbfm.2010.72] [PMID: 20571523]

[118] LaRocca, T.J.; Sosunov, S.A.; Shakerley, N.L.; Ten, V.S.; Ratner, A.J. hyperglycemic conditions prime cells for RIP1-dependent necroptosis. J. Biol. Chem., 2016, 291(26), 13753-61. [http://dx.doi.org/ 10.1074/jbc.M1 16.716027] [PMID: 27129772]

[119] Xuan, M.; Okazaki, M.; Iwata, N, et al. Chronic treatment with a water-soluble extract from the culture medium of ganoderma lucidum Mycelia prevents apoptosis and necroptosis in hypoxia/ischemiainduced injury of Type 2 Diabetic mouse brain. Evid Based Complement. Alternat. Med., 2015, 2015, 865986. [http://dx.doi.org/10. 1155/2015/865986] [PMID: 25945116]

[120] Askalan, R.; Gabarin, N.; Armstrong, E.A.; Fang, L. Y.; Couchman, D.; Yager, J.Y. Mechanisms of neurodegeneration after severe hypoxic-ischemic injury in the neonatal rat brain. Brain Res., 2015, 1629, 94-103. [http://dx.doi.org/10.1016/j.brainres.2015.10.020] [PMID: 26485031]

[121] Qu, Y.;Tang, J.; Wang, H.;Li, S.; Zhao, F.; Zhang, L.; Richard, L. Q.; Mu, D. RIPK3 interactions with MLKL and CaMKII mediate oligodendrocytes death in the developing brain. Cell Death Dis., 2017, 8(2), e2629. [http://dx.doi.org/10.1038/cddis.2017.54] [PMID: 28230861]

[122] Wang, Y.Z.; Wang, J.J.; Huangm, Y.; Liu, F.; Zeng, W.Z.; Li, Y.; Xiong, Z.G.; Zhu, M.X.; Xu, T.L. Tissue acidosis induces neuronal necroptosis via ASIC1a channel independent of its ionic conduction. eLife, 2015, 4, 4. [http://dx.doi.org/10.7554/eLife.05682] [PMID: 26523449]

[123] Dai, M.C.; Zhong, Z.H.; Sun, Y.H.; Sun, Q.F.; Wang, Y.T.; Yang, G.Y.; Bian, L.G. Curcumin protects against iron induced neurotoxicity in primary cortical neurons by attenuating necroptosis. Neurosci. Lett., 2013, 536, 41-6. [http://dx.doi.org/10.1016/j.neulet.2013.01. 007] [PMID: 23328441]

[124] Xu, X.; Chua, C.C.; Zhang, M, Geng, D.; Liu, C.F.; Hamdy, R.C.; Chua, B.H. The role of PARP activation in glutamate-induced necroptosis in HT-22 cells. Brain Res., 2010, 1343, 206-12. [http://dx. doi.org/10.1016/j.brainres.2010.04.080] [PMID: 20451505]

[125] Li, Y.; Yang, X.; Ma, C.; Qiao, J.; Zhang, C. Necroptosis contributes to the NMDA-induced excitotoxicity in rat's cultured cortical neurons. Neurosci. Lett., 2008; 447(2-3), 120-3. [http://dx.doi.org/10. 1016/j.neulet.2008.08.037] [PMID: 18723075] 